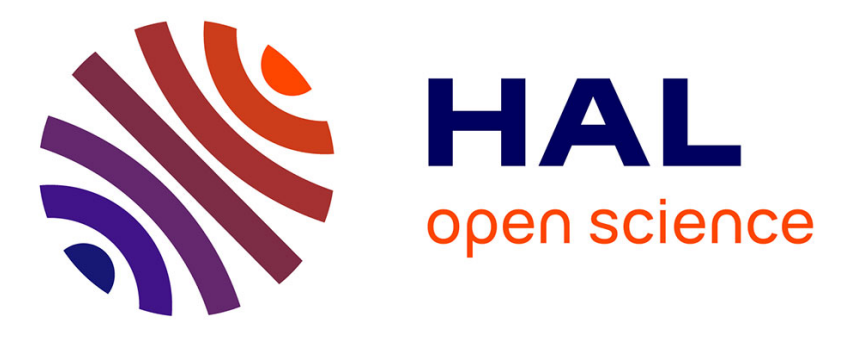

\title{
Dual-Responsive Molecular Switches Based on Dithienylethene-Ru-II Organometallics in Self-Assembled Monolayers Operating at Low Voltage
}

Andrea Mulas, Xiaoyan He, Yves-Marie Hervault, Lucie Norel, Stéphane Rigaut, Corinne Lagrost

\section{To cite this version:}

Andrea Mulas, Xiaoyan He, Yves-Marie Hervault, Lucie Norel, Stéphane Rigaut, et al.. DualResponsive Molecular Switches Based on Dithienylethene-Ru-II Organometallics in Self-Assembled Monolayers Operating at Low Voltage. Chemistry - A European Journal, 2017, 23 (42), pp.1020510214. 10.1002/chem.201701903 . hal-01578549

HAL Id: hal-01578549

https://hal-univ-rennes1.archives-ouvertes.fr/hal-01578549

Submitted on 29 Aug 2017

HAL is a multi-disciplinary open access archive for the deposit and dissemination of scientific research documents, whether they are published or not. The documents may come from teaching and research institutions in France or abroad, or from public or private research centers.
L'archive ouverte pluridisciplinaire HAL, est destinée au dépôt et à la diffusion de documents scientifiques de niveau recherche, publiés ou non, émanant des établissements d'enseignement et de recherche français ou étrangers, des laboratoires publics ou privés. 


\title{
Dual-Responsive Molecular Switches based on Dithienylethene - Ru(II) Organometallics in self-assembled monolayers operating at low voltage
}

\author{
Andrea Mulas, Xiaoyan He, Yves-Marie Hervault, Lucie Norel, Stéphane Rigaut* and Corinne Lagrost*
}

\begin{abstract}
Two carbon-rich ruthenium complexes bearing a dithienylethene (DTE) unit and a hexylthiol spacer were designed to be attached on gold surfaces. Both compounds display photochemically-driven switching properties, allowing reversible conversion from open to closed forms of the DTE units upon irradiation in solution. In contrast, only the bimetallic complex undergoes an efficient electrochemical ring closure at low potential, ( $0.5 \mathrm{~V}$ vs SCE), whereas the monometallic complex show a simple one electron reversible redox event. These appealing switching properties could be successfully transferred within diluted selfassembled monolayers (SAMs). Furthermore, the two immobilized organometallics exhibit fast electron transfer kinetics. Therefore, this organometallic strategy allows to obtain multifunctional surfaces with the possibility of combining switching events triggered by an electrochemical oxidation at low potential and by light at distinct wavelengths for a write-and-erase function, along with an access to different oxidation states. Importantly, a non-destructive electrochemical read-out is achieved at a sufficiently high scan rate that prevents any electrochemical closing. On the whole, the two surface-confined organometallic compounds exhibit appealing properties for application in molecular electronics.
\end{abstract}

\section{Introduction}

Photochromic molecules are widely used as key components in various stimuli-responsive molecular switches and machines. ${ }^{[1,2,3,4,5]}$ Commonly used photoswitchable compounds are azobenzene, spiropyrans or dithienylethene (DTE) that offer fast and clean isomerization processes. A DTE consist of two thiophene units linked to a central olefin. Upon irradiation with UV light, the open form of DTE can undergo a ring closure in which the $\pi$ system is rearranged by forming a bond between the two thiophene units. This cyclization can be reversed upon irradiation with visible light and the closed form returns back to the open form (Scheme 1). This unit is particularly interesting as a building block for photoswitches because both DTE isomers are thermally stable and they can be addressed independently owing to the difference

[a] Dr. A. Mulas, Dr X. He, Dr. Y.M. Hervault, Dr. L. Norel, Prof. S Rigaut, Dr. C. Lagrost

Institut des Sciences Chimiques de Rennes, UMR 6226 CNRS-Université de Rennes 1

Campus de Beaulieu, F-35042 Rennes Cedex, France E-mail: corinne.lagrost@univ-rennes1.fr, stephane.rigaut@univrennes1.fr

Supporting information for this article is given via a link at the end of the document.((Please delete this text if not appropriate))

in their respective UV/Visible absorption spectra. ${ }^{3}$

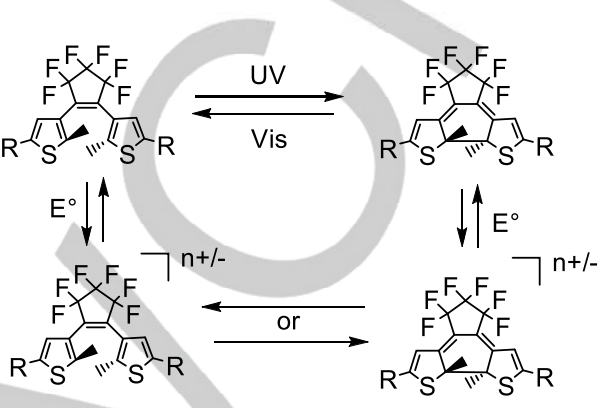

Scheme 1. DTE switching

In addition, efficient opening or closing can be reached electrochemically with many systems, ${ }^{[6,7,8,9,10,1112,13]}$ depending on the relative stabilities of the open and closed forms of the electrochemically produced species (Scheme 1). In particular, ring closure can be triggered electrochemically by oxidation of the DTE unit but it requires a relatively high potential (> $1 \mathrm{~V}$ vs SCE). ${ }^{[7]}$ Attaching an organometallic unit to a DTE unit is an excellent strategy to modulate its switching and spectroscopic properties, ${ }^{[14]}$ and to achieve multifunctional systems within a single component architecture. In that direction, we ${ }^{[15,16,17]}$ and others ${ }^{[18]}$ have shown that association of a DTE unit with a ruthenium carbon-rich system can afford photo-/electro- controllable molecular switches with attractive properties for optoelectronic devices including multicolor electrochromism, electrocyclization at remarkably low voltage (0.4- $0.5 \mathrm{~V}$ vs SCE), and to design multi-controllable molecular junctions. ${ }^{[19]}$ Hence, this example shows that metal complexes associated to photochromic units are promising candidates to be integrated in optoelectronic devices as functional materials. ${ }^{[20]}$

To be fully exploited in applications, such photochromic molecular switches must be immobilized at an interface. The fabrication of highly efficient molecular photo- / electro- devices requires the arrangement of the switches at molecular level as typically obtained in self-assembled monolayers (SAMs). ${ }^{[1]}$ DTEbased molecular switches have been successfully immobilized within SAMs at gold, ITO or silicon surfaces. ${ }^{[11,22,23,24,25,26,27,28,29]}$ However, the transposition of solution behavior for switches to their corresponding SAMs is not trivial. A key issue is the effect of surface confinement on the switching function. Generally, the redox switching is hardly affected while the optical processes can be fully or partially hampered at the vicinity of a metallic substrate because of excited states quenching, electronic relaxation effect or steric hindrance deriving from the lack of free space due to close packing of neighbouring molecules. ${ }^{[25,26,} 30$ ] The isomerization of DTE does not generally require large mechanical motion, and steric hindrance is not reported as a limiting factor for this system. However, this behavior usually concerns rather simple DTE architecture. A critical point for the successful operation of the photo-responsive unit is the spacing between the 
anchoring unit and the photochrome in order to minimize the through space-interaction with the surface. A few angstroms (> 6$7 \AA$ ) allow to efficiently overcome this issue. ${ }^{[25,31]}$ However, the linker should not be too long because a certain level of communication between the surface and the molecular switch must be maintained for making the molecular devices operative, in particular from a redox point of view.

To obtain efficient electro- and photo-switched systems based on the DTE-metal complexes, several properties are desired: i) specific wavelengths in order to address the photoswitching independently, ii) low redox potentials associated to the electroswitching for low power consumption, and iii) a nondestructive and fast read-out mechanism to determine the molecular isomeric state of the switch. Considering this last point, electrochemistry is particularly relevant because DTE systems in general and the DTE-Ru(II) organometallics considered in this work in particular lead to fully distinguishable signals characteristic of the two isomers. Moreover, ruthenium complexes exhibit fast electron-transfer kinetics $\left(10^{4} \mathrm{~s}^{-1}\right),{ }^{[32,33]}$ which is required for efficient information processing at the shortest timescale. ${ }^{[34]}$

In this context, we have functionalized two DTE carbon-rich ruthenium complexes with a hexylthiol unit for incorporation as SAMs at gold surfaces (Scheme 2), choosing as spacer the six carbon chain in order to accurately separate (vide supra) the switching unit from the surface by c.a. $8.9 \AA$ (estimation through molecular mechanics energy minimization by using Chem3D software). The organometallic switches differ in the number of Ru complexes associated to the DTE moiety, and thus in their electrochemical behavior. The switching properties were first evaluated in solution by cyclic voltammetry, showing the expected striking effect of the bimetallic Ru complexes 8 towards electroswitching at low redox potentials. Single-component or mixed SAMs with co-adsorption of hexylthiol as diluent were formed from both complexes. After characterization of the SAMs by contact angle measurements, $X$-ray Photoelectrons Spectroscopy (XPS) and electrochemical analyses, the properties of the surface-confined organometallic switches were investigated, highlighting (i) reversible photoswitching for 60 and 80 in mixed monolayers, (ii) electroswitching at remarkably low potential for 8o, (iii) fast and non-destructive electrochemical read-out for both systems and access to distinct stable oxidation states. These results show that the combination of DTE photochromic unit and ruthenium carbon-rich complex within a single molecular system, immobilized at a gold surface, is suitable for building dual-responsive multifunctional systems.

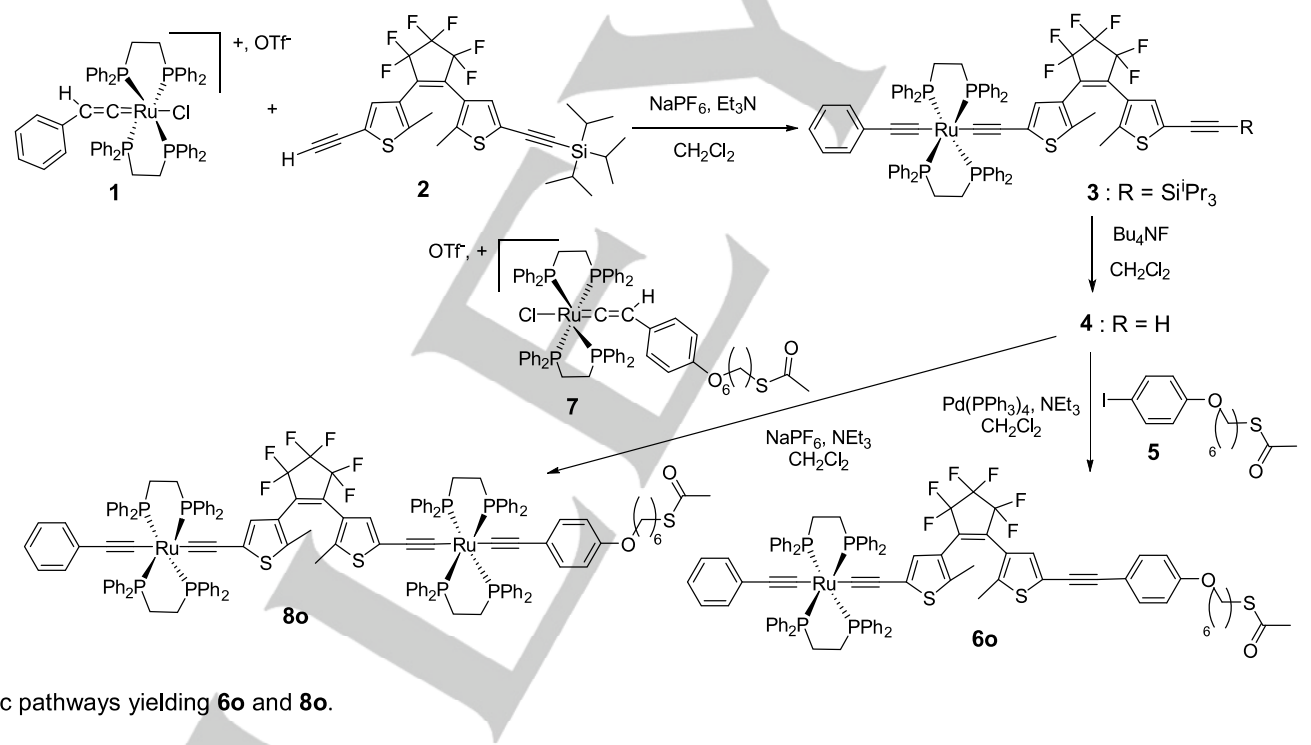

Scheme 2. Synthetic pathways yielding 60 and 80 .

\section{Results and Discussion}

\section{Synthesis of organometallic switches 60 and 80}

The synthetic routes to the targeted complexes 60 and 80 are displayed in scheme 2 . First, following the general procedure to prepare bis $\left(\sigma\right.$-arylacetylide) ruthenium complexes, ${ }^{[16,17,35]}$ reaction of the accurate metal-vinylidene trans-[CIRu(dppe $)_{2}=\mathrm{C}=\mathrm{CH}$ $\mathrm{Ph}](\mathrm{OTf}) \mathbf{1}$ and of the ethynyl-substituted dithienylethene $\mathbf{2}$ in the presence of a non-coordinating salt $\left(\mathrm{NaPF}_{6}\right)$ and a base $\left(\mathrm{Et}_{3} \mathrm{~N}\right)$ led to the bis $(\sigma$-arylacetylide) complex 3 ( $72 \%$ yield). The second ethynyl function of the DTE unit of compound 3 was then deprotected in the presence of fluoride to afford 4 , which is the precursor for the two targeted complexes. Complex 60 was prepared through a Sonogashira coupling between 4 and I-1,4$\mathrm{C}_{6} \mathrm{H}_{4}-\mathrm{O}-\left(\mathrm{CH}_{2}\right)_{6}-\mathrm{SAc}(5)$ bearing the thioacetate function. Then, starting again from 4 and from the metal vinylidene trans$\left.\left[(\mathrm{dppe})_{2}(\mathrm{Cl}) \mathrm{Ru}=\mathrm{C}=\mathrm{CH}-p-\mathrm{C}_{6} \mathrm{H}_{4}-\mathrm{O}-\left(\mathrm{CH}_{2}\right)_{6}-\mathrm{SAc}\right)\right](\mathrm{OTf})(7)$, complex 80 was obtained in moderate yield (55\%) using the same reaction conditions as those used to obtain 3. All new organometallic species were characterized by ${ }^{31} \mathrm{P},{ }^{1} \mathrm{H},{ }^{13} \mathrm{C} N M R$, IR, and mass 
spectroscopies. FTIR measurements show the expected characteristic $v_{\mathrm{C} \equiv \mathrm{C}}$ vibration stretch around $2050 \mathrm{~cm}^{-1}$ for the acetylide functions of $\mathbf{3}, \mathbf{4 , 6 0}$ and $\mathbf{8 0}$ and the $v_{\mathrm{C}=\mathrm{o}}$ around 1690 $\mathrm{cm}^{-1}$ for the protected thiol functions of 60 and 80 . The trans arrangement on the ruthenium centers in each complexes were established by the observation of a single resonance peak in the ${ }^{31} \mathrm{P}$ NMR spectra for the four phosphorus atoms for each ruthenium centers in the typical regions for bis $(\sigma$-arylacetylide $)$ at ca. $\delta=55 \mathrm{ppm}$. The ${ }^{1} \mathrm{H}$ NMR spectra of compound 60 and 80 display characteristic resonance for the photochromic bridge with a single peak for the methyl protons at $\delta=1.79 \mathrm{ppm}$ and one for the two protons on the thiophene units at $\delta=6.23 \mathrm{ppm}$ for 80 in $\mathrm{CD}_{2} \mathrm{Cl}_{2}$ as an example.

\section{UV-visible spectra / Photoisomerization Studies of 60 and 80 in solution}

The two complexes 60 and 80 display an intense absorption band with a large extinction coefficient at $\lambda_{\max }=332$ and $347 \mathrm{~nm}$, respectively (Figure 1, Table 1).
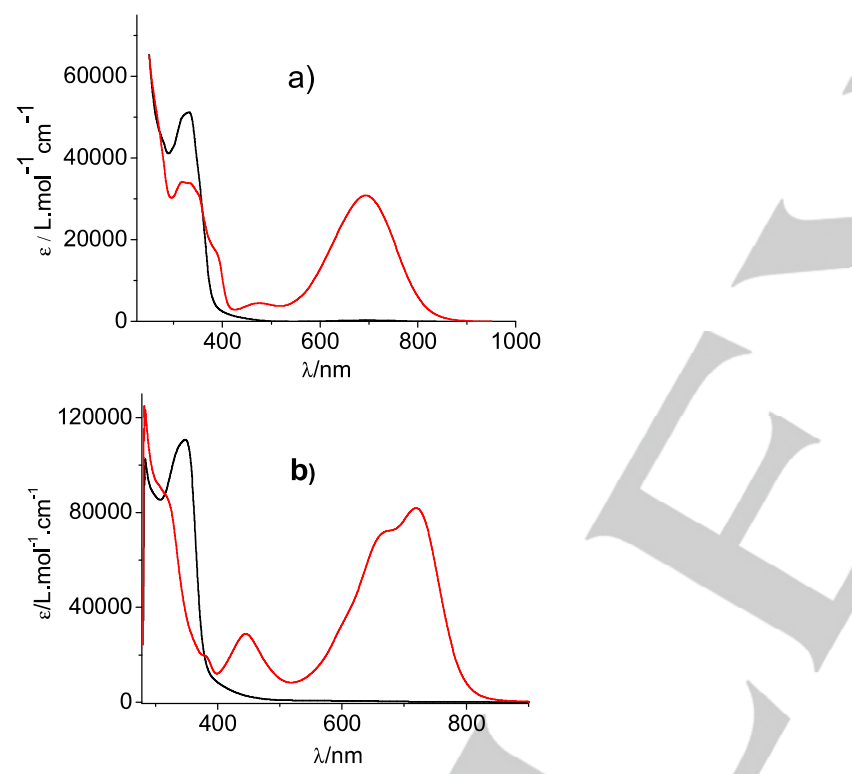

Figure 1. UV-Vis absorption spectra of (a) $60\left(\mathrm{CH}_{2} \mathrm{Cl}_{2}\right)$ and (b) 80 (toluene) before (black line) and after irradiation $15 \mathrm{~min}$ at $\lambda=350 \mathrm{~nm}$ to the PSS (red line) $\left(C \approx 10^{-5} \mathrm{~mol} / \mathrm{L}\right)$.

The theoretical studies previously reported for such ruthenium species have revealed that the transition associated to first excited state mainly corresponds to an HOMO $\left(\mathrm{Ru}_{\mathrm{d} / \pi}\right) \rightarrow$ LUMO $\left(\mathrm{DTE}_{\pi^{*}}\right)$ allowed excitation. ${ }^{[15,16]}$ This $\mathrm{d} / \pi(\mathrm{RuC} \equiv \mathrm{C})$ to $\pi^{*}(\mathrm{DTE})$ excitation induces enough accumulation of electron density on two carbon atoms of the DTE for the creation of a single $\mathrm{C}-\mathrm{C}$ bond upon rotation leading to the closed form. Therefore, the complete isomerization process upon irradiation with UV light $(350 \mathrm{~nm})$ leads to the very stable $6 \mathrm{c}-8 \mathrm{c}$ complexes in the UV-vis cell $([\mathrm{c}] \approx$ $10^{-5} \mathrm{~mol}^{-\mathrm{L}^{-1}}$ ) (Scheme 3).

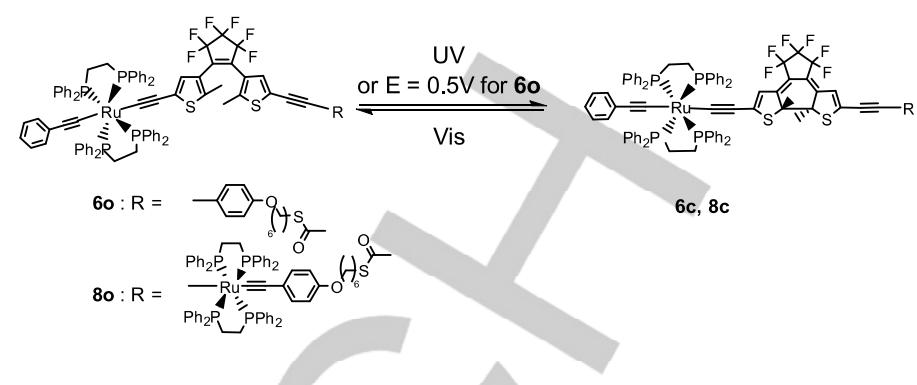

Scheme 3. Isomerization processes of 60 and 80 .

Typically, upon irradiation of 60 at $350 \mathrm{~nm}$ in the UV band related to transitions involving the DTE unit, this band decreases while a broad absorption typical of the closed DTE units appears at $\lambda_{\max }$ $=693 \mathrm{~nm}$ and is assigned to the closed isomer $6 \mathrm{c}$. For $8 \mathrm{c}$, the band is located at $\lambda_{\max }=719 \mathrm{~nm}$ with a shoulder at $676 \mathrm{~nm}$. The broadening of this lower lying band is now well known for such bimetallic species and is due to the presence of several rotamers of close energies (Ru(dppe) $)_{2}$ rotations toward the DTE plane). ${ }^{[15,16]}$ For this closed form, the first excited state is mainly described by an HOMO to LUMO transition $\mathrm{M}_{\mathrm{d} / \pi^{-}}-\mathrm{C}_{2} \mathrm{DTE}_{\pi} \rightarrow \mathrm{M}_{\mathrm{d} / \pi^{-}}$ $\mathrm{C}_{2} \mathrm{DTE}_{\pi^{*}}$ that induces the loss of bonding density between the methylated carbon atoms and thus eventually the bond breaking.

Table 1. Selected ${ }^{1} \mathrm{H}$ and ${ }^{31} \mathrm{P}$ NMR chemical shifts, UV-Vis absorption spectra of 60 and 80 and spectral changes upon irradiation at $\lambda=350 \mathrm{~nm}$.

\begin{tabular}{|c|c|c|c|c|}
\hline & ${ }^{1} \mathrm{HNMR}^{\mathrm{a}}$ & $\begin{array}{r}{ }^{31} \mathrm{P} \\
\mathrm{NMR}^{\mathrm{a}} \\
\end{array}$ & $\begin{array}{c}\mathrm{IR} \\
(\mathrm{KBr})\end{array}$ & UV-visible ${ }^{b}$ \\
\hline & $\begin{array}{c}\delta \mathrm{CH}_{3}{ }^{\mathrm{DTE}} \\
\mathrm{ppm}\end{array}$ & $\begin{array}{l}\text { dppe } \\
\text { ppm }\end{array}$ & $\begin{array}{l}v_{\mathrm{C} \equiv \mathrm{C}} \\
\mathrm{cm}^{-1}\end{array}$ & $\begin{array}{c}\lambda_{\max }(\varepsilon) \\
\mathrm{nm}\left(L \cdot \mathrm{mol}^{-1} \cdot \mathrm{cm}^{-1}\right)\end{array}$ \\
\hline 60 & $1.84,1.95$ & & 2052 & $332(51219)$ \\
\hline $6 c$ & 2.15 & 52.1 & 2009 & $\begin{array}{c}319(34137), 334(33903) \\
693(30842)^{\mathrm{c}}\end{array}$ \\
\hline 80 & 2.00 & $\begin{array}{l}53.8 \\
53.7\end{array}$ & 2054 & $347(110800)$ \\
\hline $8 c$ & 2.66 & 53.1 & 2015 & $\begin{array}{c}310 \text { (89600), } 376(19960), \\
444(28840), 676(72400), \\
719(82920)^{c}\end{array}$ \\
\hline
\end{tabular}

a in $\mathrm{CD}_{2} \mathrm{Cl}_{2}$ for 6 and in $\mathrm{C}_{6} \mathrm{D}_{6}$ for $8{ }^{\mathrm{b}}$ in $\mathrm{CH}_{2} \mathrm{Cl}_{2}$ for 6 and in toluene for 8. ${ }^{\circ} \mathrm{PSS}$. The initial spectrum was recovered after bleaching at $\lambda=750 \mathrm{~nm}$ or $650 \mathrm{~nm}$.

Complete conversion of 80 to $8 \mathrm{c}$ was detected through ${ }^{31} \mathrm{P}$ and ${ }^{1} \mathrm{H}$ NMR studies with identification of the characteristic downfield shifts of the methyl group protons and a slight upfield shift of the phosphorus atoms resonance (Table 1). Almost complete conversion to $6 \mathrm{c}(96 \%)$ is obtained at the PSS (photo stationary state). The $v_{\mathrm{C} \equiv \mathrm{C}}$ vibration stretch is also systematically shifted upon ring closure to a lower wavenumber by ca. $40 \mathrm{~cm}^{-1}$ which is consistent with an increased conjugation. Both solutions at the PSS can be bleached under visible light at $650 \mathrm{~nm}$ and $750 \mathrm{~nm}$ to recover 60 and 80 , respectively, with quantitative recovering of the initial spectra. 


\section{Electrochemical Studies of 60 and 80 in solution}

Cyclic voltammograms (CV) were recorded in $\mathrm{CH}_{2} \mathrm{Cl}_{2}$ containing $0.2 \mathrm{M} \mathrm{Bu}_{4} \mathrm{NPF}_{6}$ to study the redox properties of 60 and 80 . Concerning 60 , a reversible one-electron oxidation system is observed at $\mathrm{E}_{1}{ }^{\circ}=0.41 \mathrm{~V} / \mathrm{SCE}(\Delta \mathrm{Ep}=60 \mathrm{mV})$ typical of ruthenium acetylide oxidation, followed by an irreversible process $\left(\mathrm{E}_{\mathrm{pa} 2}=\right.$ $1.31 \mathrm{~V} / \mathrm{SCE}$ ) strongly reminiscent of the usual oxidation potential reported for the DTE core and/or additional ruthenium oxidation. ${ }^{[14,36]}$ UV irradiation at $\lambda_{\max }=350 \mathrm{~nm}$ was further performed in the electrochemical cell and led to a less positive oxidation process for $6 \mathrm{c}$ at $\mathrm{E}_{1}{ }^{\circ}=0.35 \mathrm{~V} / \mathrm{SCE}(\Delta \mathrm{Ep}=80 \mathrm{mV})$, owing to the more conjugated character of the acetylide moiety (Figure $\mathrm{S} 1)$. This process is also followed by an irreversible process ( $E_{\mathrm{pa} 2}$ $=0.92 \mathrm{~V} / \mathrm{SCE}$ ). Cyclic voltammetry of $\mathbf{8 0}$ presents a partially reversible broad redox system at $0.43 \mathrm{~V} / \mathrm{SCE}$ which is composed of two close one-electron oxidation processes corresponding to the two electronically independent metal fragments and leading to $8 \mathbf{0}^{2+}$ (Figure 2). ${ }^{[15,16,19]}$

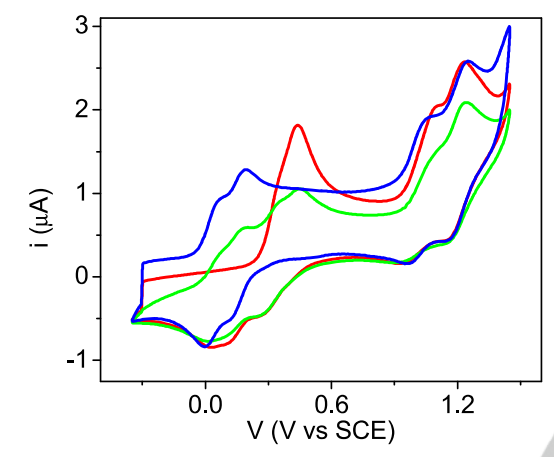

Figure 2. $\mathrm{CV}$ at a Pt electrode $\left([\mathrm{C}]=10^{-3} \mathrm{~mol} . \mathrm{L}^{-1}, 0.2 \mathrm{~mol}^{-L^{-1}} \mathrm{Bu}_{4} \mathrm{NPF} 6, \mathrm{v}=0.1\right.$ $\mathrm{V} . \mathrm{s}^{-1}$ ) of 80 (first scan, red line and after $1 \mathrm{~min}$ electrolysis at $0.6 \mathrm{~V}$, green line), and of $8 \mathrm{c}$ after UV irradiation $\left(15 \mathrm{~min}\right.$ ) of 80 at $\lambda_{\max }=350 \mathrm{~nm}$ (PSS, blue line)

Consecutively, two new redox systems appear at less positive potentials on the return scan. These new redox systems are wellseparated and correspond to two reversible processes $(0.06$ V/SCE and $0.19 \mathrm{~V} / \mathrm{SCE}, \Delta \mathrm{Ep}=60-70 \mathrm{mV}, \mathrm{i}_{\mathrm{pa}} / \mathrm{i}_{\mathrm{pc}}=1$ ) as can be seen on the second following scan. They are ascribed to the $8 \mathrm{c}^{+} / 8 \mathrm{c}$ and $8 \mathrm{c}^{2+} / 8 \mathrm{c}^{+}$redox processes involving the closed isomer that is electrochemically produced from a radical-radical coupling in bimetallic species as observed with parent complexes (Scheme S1) ${ }^{[15,16]}$ a phenomenon that cannot occur with monometallic complexes such as 6o. Logically, identical waves are obtained after photoconversion of 80 to $8 \mathrm{c}(\lambda=350 \mathrm{~nm})$, along with the disappearing of the broad peak at $0.43 \mathrm{~V}$. Two further oxidations are observed at higher potential $\left(E_{p a}=1.14 \mathrm{~V}\right.$ and $E_{p a}=1.26 \mathrm{~V}$ for 80) reminiscent of the usual oxidation potential reported for the DTE core and/or additional ruthenium oxidation.

\section{Integration of the organometallic switches in SAMs}

Self-assembled monolayers of 60 and 80 on gold were prepared by immersing gold coated silicon substrates or gold disk electrodes into a solution of 60 or 80 in $\mathrm{CH}_{2} \mathrm{Cl}_{2}$ for $16 \mathrm{~h}$. The thioacetate group was deprotected in situ by addition of $\mathrm{NH}_{4} \mathrm{OH}$ (aq) to the preparation solution before immersion of the gold surface. ${ }^{[37,38]}$ Mixed self-assembled monolayers were obtained by co-adsorption with hexane-1-thiol (introduced in 10:1 ratio in the preparation solution). ${ }^{[32]}$ Water contact angle measurements were performed on single component SAMs by using the sessile drop method. After a thorough rinsing and drying under argon, the static angle of the modified gold surfaces was found equal to 96 $\pm 2^{\circ}$ and $99 \pm 2^{\circ}$ for surfaces modified with 60 and 80 , respectively. For the bare gold surfaces, the contact angle was 60 $\pm 2^{\circ}$. These measurements indicate the formation of hydrophobic layers after immersing of the gold substrates in solutions containing 60 and 80 , as expected regarding the hydrophobic nature of the organometallic switches. XPS measurements were performed to study the composition of mixed SAMs incorporating 60 and 80 . C, Ru, P, S, O and F elemental species can be identified in survey and high-resolution core level spectra. Intense $\mathrm{Au} 4 \mathrm{f}$ photoelectrons peaks $(83.9 \pm 0.5 \mathrm{eV})$ are observed, suggesting the formation of ultrathin layers as expected for SAMs. For both SAMs, the signals of Ru $3 d_{5 / 2}$ at $280.7 \pm 0.2 \mathrm{eV}$ (the Ru $3 \mathrm{~d}_{3 / 2}$ component at $284.9 \mathrm{eV}$ overlaps with the intense $\mathrm{C} 1 \mathrm{~s}$ peak), $P 2 p$ at $131.2 \pm 0.2 \mathrm{eV}$ and $F 1 \mathrm{~s}$ at $687 \pm 0.2 \mathrm{eV}$ are good tags to assess the presence of the organometallic switches at the gold surfaces. It is further interesting to analyze the core level spectra for $S 2 p$ and $C 1 s$. $S 2 p$ is decomposed into a pair of doublet components, due to spin-orbit splitting (Figure 3 ). The $S 2 p_{3 / 2}$ and $S 2 p_{1 / 2}$ peaks are fitted using a 2:1 peak area ratio and a $1.2 \mathrm{eV}$ splitting. One pair of doublet at $161.8 \pm 0.5 \mathrm{eV}(\mathrm{S} 2 \mathrm{p} \mathrm{3/2})$ is assigned to sulfur bonded to gold, originating from the chemisorbed thiolates of the organometallic switches and the diluent. $^{[11,22,25,39,40,41]}$ There are no significant contributions from oxidized sulfur species typically observed at $168 \mathrm{eV}$. This indicates that the deprotection of 60 and 80 occurs via cleavage of the S-Ac bond, allowing the formation of a bond with the gold surface. In agreement with this observation, the oxygen 1s core level spectra display only one component at $532.6 \pm 0.2$ and signals assignable to $\mathrm{C}=\mathrm{O}$ expected at $531-531.5 \mathrm{eV}$ are absent from the spectra. A second pair of doublet is observed in the two spectra at $163.8 \pm 0.5 \mathrm{eV}\left(\mathrm{S} 2 \mathrm{p}_{3 / 2}\right)$ and corresponds to the thiophene groups in DTE. ${ }^{[11,25]}$ The carbon 1s core level spectra are fitted with 5 components and comprise the doublet pair for $\mathrm{Ru}$ $3 \mathrm{~d}$ (Figure 3). The dominant component at $285 \pm 0.2 \mathrm{eV}$ accounts for the aliphatic and aromatic $\mathrm{C}-\mathrm{C}$ and $\mathrm{C}-\mathrm{H}$ bonds. Signals at $285.6 \pm 0.2 \mathrm{eV}$ are assigned to carbons bound to $S$ and $P$, while contributions at $286.5 \pm 0.2 \mathrm{eV}$ correspond to the $\mathrm{C}-\mathrm{O}-\mathrm{C}$ group in 60 and 80 . Weak signals at $283 \pm 0.2 \mathrm{eV}$ are due to carbons bound to the ruthenium metallic centers. ${ }^{[22,32]}$ Interestingly, small contributions at $291 \pm 0.3 \mathrm{eV}$ are observed, originating from the $\mathrm{CF}_{2}$ groups in the DTE moiety. Accordingly, this component is less visible for 80 than for $60, \mathrm{CF}_{2}$ contributions being logically more mitigated in the former than in the latter regarding the overall C composition. The calculated F/P ratios of 1.55 for 60 and 1.02 for 80 are close to the expected values (1.5 and 0.75 , 
respectively). All these results indicate the formation of SAMs

incorporating 60 and 80 on gold surfaces.
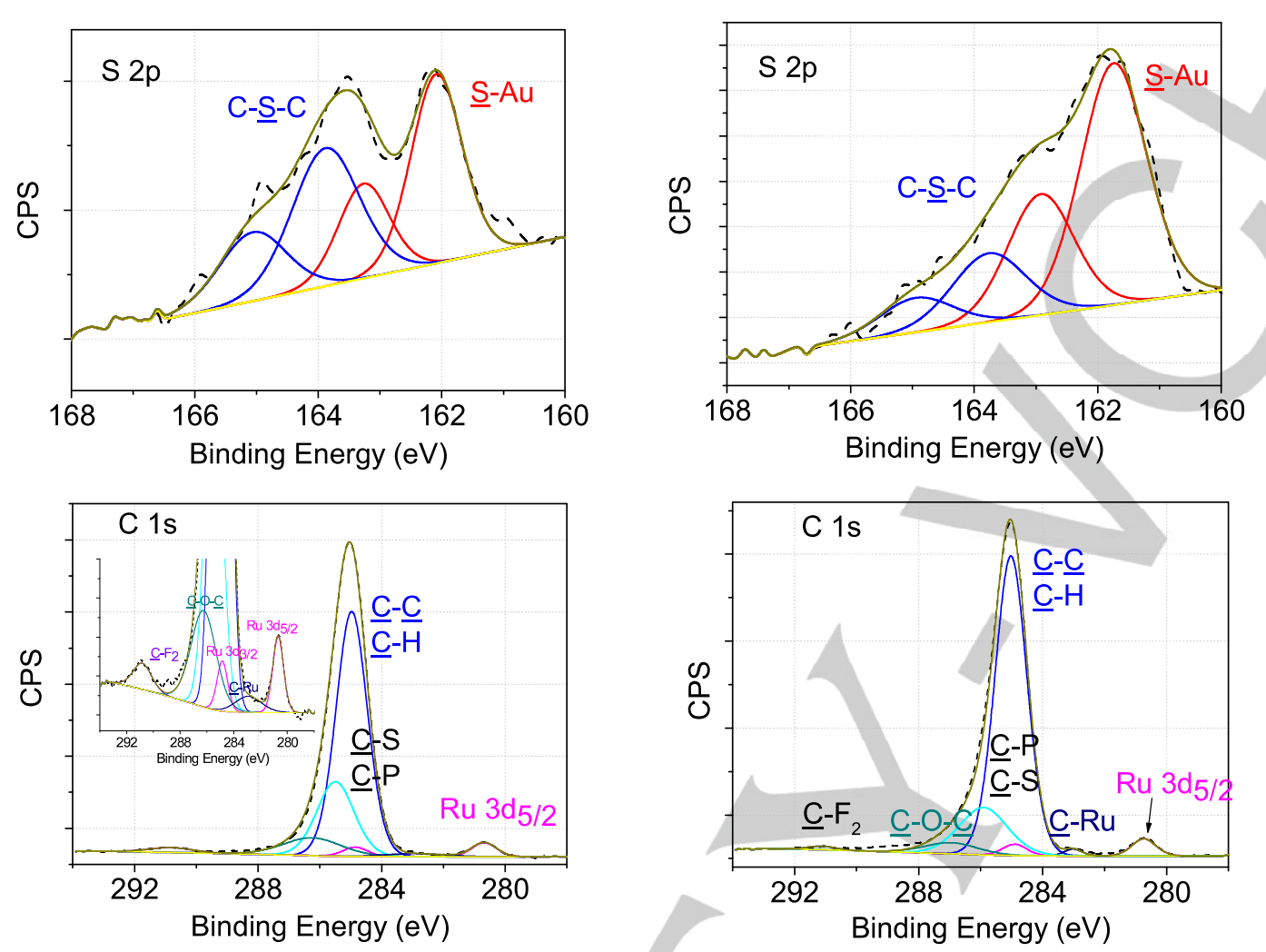

Figure 3. Peak-fitted S $2 p$ and $C$ 1s core level spectra for gold substrates modified with 60 (left) and 80 (right).

\section{Electrochemical studies on the switching of the organometallics within SAMs}

Cyclic voltammetry was recorded for single-component SAMs incorporating 60 both on gold ultramicroelectrodes and millimetric electrodes in $\mathrm{CH}_{2} \mathrm{Cl}_{2}$ containing $\mathrm{NBu}_{4} \mathrm{PF}_{6}$ as supporting salt. Figure 4 shows a typical voltammogram at a $5 \mu \mathrm{m}$ electrode. A well-resolved redox signal corresponding to the one-electron reversible oxidation of the ruthenium-acetylide complex is observed at $\mathrm{E}^{\circ}=0.43 \mathrm{~V}$ vs SCE, very close to the formal potential value observed in solution. In the studied potential range, the electrochemical signal remains fully reversible in a large range of scan rates, i.e. $[50 \mathrm{mV} / \mathrm{s}-7 \mathrm{kV} / \mathrm{s}]$, indicating that there is no electrochemical switching for this compound as observed in solution. Surface concentration $\Gamma$ derived from the integration of the electrochemical signal is found equal to $4.6 \pm 0.3 \times 10^{-11} \mathrm{~mol}$ $\mathrm{cm}^{-2}$, in agreement with the formation of a (sub-) monolayer. The very good stability of the SAM upon many repeated cycles allows a clean study of the electronic transfer dynamics. Applying the Laviron formalism, ${ }^{[42]}$ the apparent kinetic rate constant could be estimated from the trumpetlike graphs in the Laviron representation (Ep-log v plots) (Figure S3) (eq1).

$$
k_{E T}=(1-\alpha) \cap F v_{i} / R T
$$

where $\alpha$ is the transfer coefficient, $n$ the number of electron exchanged (here $n=1$ ), $F$ the Faraday' s constant, $R$ the gas constant, $T$ is $293 \mathrm{~K}$ and $v_{i}$ is the intercept of the linear regions in the $E_{p}$-log $v$ plots.

Assuming $\alpha=0.5$, the slopes for the linear regions at high scan rates are found as $140-160 \mathrm{mv} /$ decade, close to the expected value equal to $2.3 \mathrm{RT} /(1-\alpha) F$, that is $116 \mathrm{mV} / \mathrm{s}$, allowing the determination of $k_{E T}$ with $\alpha=0.5$. Fast kinetics is determined for the charge-transfer within the self-assembly of 60 with $k_{E T}=2.9$ $x 10^{4} \mathrm{~s}^{-1}$ in agreement with previous works dealing with analogous non photochromic systems. ${ }^{[32,33]}$ This is an important consideration for application of such materials in data storage devices because the electron-transfer process through the metalSAM interface will determine the "macroscopic" response time of devices.

Photochemical switching of 60 in the single-component SAM was tentatively performed by irradiation at $350 \mathrm{~nm}$ for $30 \mathrm{~min}$ to $2 \mathrm{hrs}$. The electrochemical signal recorded after irradiation did not vary, showing that the solid-state irradiation did not lead to the closed isomer under these conditions. Similar observations were reported by Feringa, Browne and co-workers with hexafluorodithienylcyclopentene switches self-assembled onto gold planar surfaces. ${ }^{[11]}$ After dilution of 60 with hexylthiol (1:10), despite the decrease of electroactive signal, a shift of the electrochemical signal towards more negative potentials can be clearly observed upon irradiation at $365 \mathrm{~nm}$ (Figure 4) and subsequent 
photochemical ring closure of $60\left(E^{\circ}=0.45 \mathrm{~V}\right.$ vs SCE) to $6 c\left(E^{\circ}\right.$ $=0.39 \mathrm{~V}$ vs SCE) within the SAM.
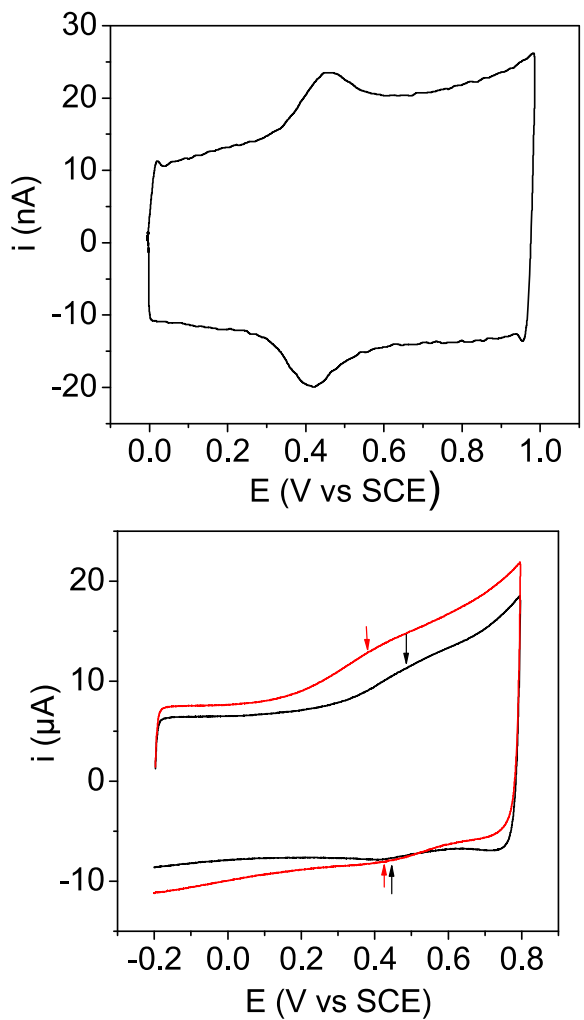

Figure 4. Cyclic voltammetry of (top) single component SAM of 60 at a $5 \mu \mathrm{m}$ electrode, scan rate is $1 \mathrm{kV} \mathrm{s}^{-1}$; (bottom) mixed SAM of 60 with hexylthiol $(1: 10)$ at $1.6 \mathrm{~mm}$ electrode (black line) and after irradiation at $350 \mathrm{~nm}$ (red line) for 90 $\mathrm{min}$, scan rate is $50 \mathrm{~V} \mathrm{~s}^{-1}$.

In sharp contrast, electrochemical switching of SAM of $8 \mathrm{o}$ to $\mathbf{8 c}$ is detected upon oxidation, as observed in solution. A signal at ca. $0.5 \mathrm{~V}$ corresponding to two very close monoelectronic

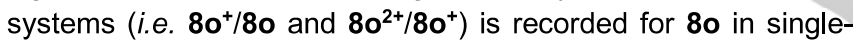
component SAM, similarly to the electrochemical behavior observed in solution. Cycling between -0.2 and $0.8 \mathrm{~V}$ at low scan rates leads to the appearance of two reversible well-separated redox systems at $\mathrm{Ec}_{1}{ }^{\circ}=0.08 \mathrm{~V}$ and $\mathrm{E}_{\mathrm{c} 2}{ }^{\circ \prime}=0.18 \mathrm{~V}$ (for $8 \mathrm{c}^{+} / 8 \mathrm{c}$ and $8 \mathrm{c}^{2+} / 8 \mathrm{c}^{+}$), indicating the electrochemical-triggered ring closure of the DTE unit (Figure 5). Note that the formal potential values are also very close to those reported in solution. The peak-to-peak separations for the first and second redox-processes are found to be $21 \mathrm{mV}$ and $24 \mathrm{mV}$, respectively at $5 \mathrm{~V} \mathrm{~s}^{-1}$, close to ideal values for surface-confined species exhibiting fast kinetics. After repetitive cycles at $10 \mathrm{mV} \mathrm{s}^{-1}$, a full conversion of 80 to $8 \mathrm{c}$ in SAM is obtained and the modified gold electrodes could be cycled several times, at different scan rates ranging from $5 \mathrm{~V} \mathrm{~s}^{-1}$ to 1000 $\mathrm{V} \mathrm{s}^{-1}$ without any desorption of the monolayer (Figure S4). From integration of the electrochemical signals, surface concentration is found to be $\Gamma=1.8 \pm 0.2 \times 10^{-11} \mathrm{~mol}$. $\mathrm{cm}^{-2}$ (for both SAM of 80 and $8 \mathrm{c}$ ) a value slightly lower than for 60 probably due to the larger steric hindrance of $\mathbf{8 0}$. Interestingly, the electrochemical switching from $\mathbf{8 0}$ to $\mathbf{8 c}$ does not occur if the potential cycling is performed at high scan rates $\left(>5 \mathrm{~V} \mathrm{~s}^{-1}\right)$ : the electrochemical signal of $\mathbf{8 0}$ in SAM remains fully reversible with a typical shape showing the presence of two close redox systems $\left(\Delta \mathrm{E}^{\circ} \approx 75-80\right.$ $\mathrm{mV}$ ) (Figure 5). In our previous works, we have shown through a study performed in solution that the electrochemically-triggered isomerization process is indeed a slow process, especially for the $\operatorname{bis}(\mathrm{Ru}(\mathrm{II}) \quad \operatorname{bis}(\sigma$-arylacetylide)$)$-DTE complex bearing phenylacetylide groups as remote ligands $\left(k \approx 15 \mathrm{~s}^{-1}\right){ }^{[15,16]}$ Similarly to SAM of $\mathbf{8 c}$, the SAM of $\mathbf{8 0}$ could be cycled several times in the range [5-3000 $\left.\mathrm{V} \mathrm{s}^{-1}\right]$ without any depletion. This behavior opens the possibility of a "non-destructive" read out at high speed oxidation/reduction cycles. Concerning the electrontransfer kinetics of 80 within SAMs, contrariwise to 60 , the Laviron plots cannot be used to extract the kinetics because the two oxidation systems of 80 are located too close to each other $(\approx 70$ $\mathrm{mV}$ of peak separations) and they tend to merge at high scan rates. The apparent kinetic rate constants were then estimated through numerical simulations of the cyclic voltammograms using KISSA software. ${ }^{[43,44]}$ As for 60 , fast electron-transfer kinetics were reached and $k_{E T}$ values were found to be on the order of $10^{4}$ $\mathrm{s}^{-1}$.

Photochemical isomerization was also successfully carried out by irradiating a gold surface modified with 80 at $350 \mathrm{~nm}$ (Figure 5). A further re-opening of the DTE ring could be performed upon irradiation at $750 \mathrm{~nm}$ of $8 \mathrm{c}$ in SAM (Figure 5).
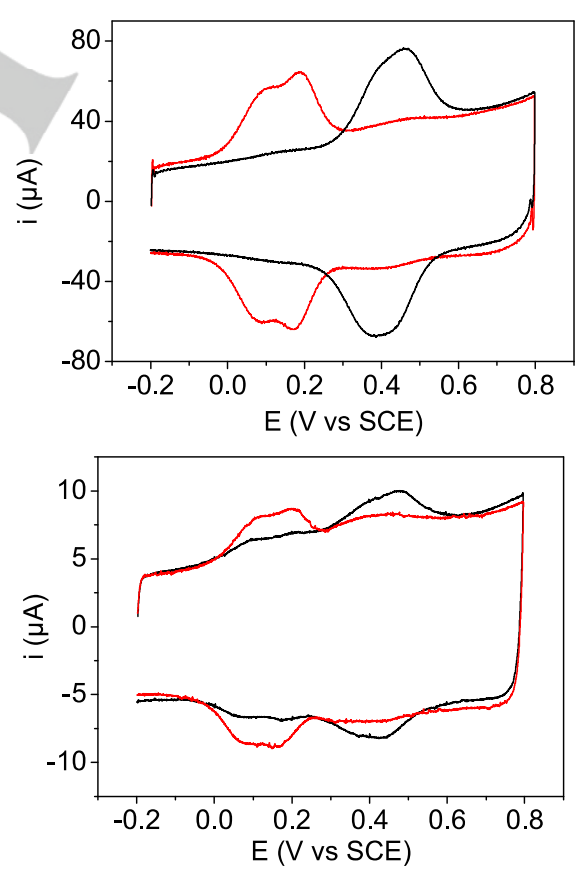

Figure 5. Cyclic voltammograms in $\mathrm{CH}_{2} \mathrm{Cl}_{2}$ containing $\mathrm{NBu}_{4} \mathrm{PF}_{6}$ of singlecomponent SAMs on a gold disk electrode $(\varnothing 1.6 \mathrm{~mm}$ ). (top) SAM of 80 (black line) and $8 \mathrm{c}$ (red line), scan rate is $100 \mathrm{~V} \mathrm{~s}^{-1}$. SAM of $8 \mathrm{c}$ is obtained after cycling of SAM of 80 with 5 repetitive cycles between -0.2 and $0.8 \mathrm{~V}$ at $10 \mathrm{mV} \mathrm{s}^{-1}$. (Bottom) SAM of $8 \mathrm{c}$ (red line) obtained after $50 \mathrm{~min}$ irradiation at $350 \mathrm{~nm}$ of SAM of 80 followed by a further irradiation at $750 \mathrm{~nm}$ (black line) for $30 \mathrm{~min}$, scan rate is $20 \mathrm{~V} \mathrm{~s}^{-1}$

A versatile control of the DTE unit is then obtained for the organometallic 80 immobilized in SAM, with both photo or electroactivation for the "write" process and a photo- activation of the 
"erase" process, along with possible non-destructive read out from electrochemical cycling at high scan rates that do not lead to cyclisation. Thus, combination of the two orthogonal stimuli is possible to switch the immobilized molecular system, making it particularly attractive. As an illustration, Figure 6 shows the electrochemical response of a mixed SAM incorporating 80 (coadsorption with hexylthiol (1:10)) showing the high sensitivity and exhibiting a sequence of switching processes: a photochemical ring closure upon irradiation at $350 \mathrm{~nm}$, then a re-opening by irradiating at $750 \mathrm{~nm}$, and finally a second ring closure but triggered by electrochemical oxidation at low scan rate.

Interestingly, successive switching processes (up to 5) could be performed without significant loss of signal and/or full conversion, provided that $\mathbf{8 0}$ is immobilized within the mixed SAM. Indeed, in some experiments with single-component SAM we observed either an incomplete conversion (78-82\% of the active molecules are converted as calculated from integration of voltammetric signal in figure 5), namely in case of re-opening, or/and a partial loss of signal after irradiation. On the other hand, the photochemical switching of single-component SAM of 60 cannot be achieved as noted above. These observations suggest that the molecular organometallic switch requires a certain degree of freedom regarding its footprint probably because of a necessary reorganization within the monolayer after isomerization. Such a behavior has been sometimes reported for azobenzene photoswitches because the isomerization in these systems is accompanied by a strong geometrical change. Close-packing of the molecular switches is deleterious for an efficient photoswitching and dilution with an inactive thiol was reported to efficiently fix this issue. ${ }^{[45,46,47,48]}$
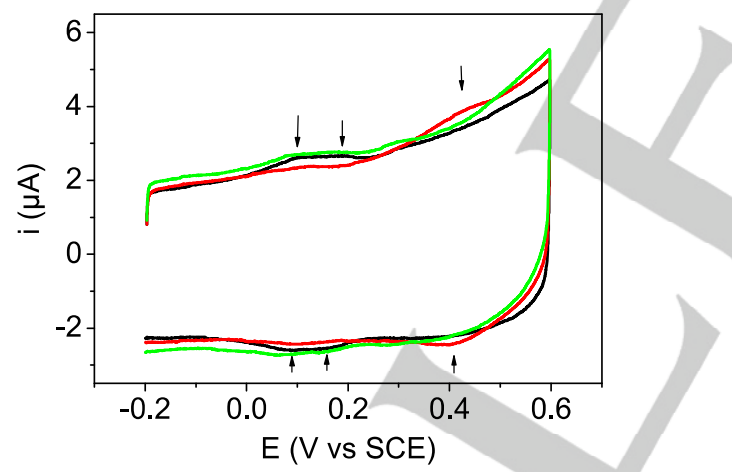

Figure 6. Cyclic voltammograms in $\mathrm{CH}_{2} \mathrm{Cl}_{2}$ containing $\mathrm{NBu}_{4} \mathrm{PF} 6$ of a mixed $\mathrm{SAM}$ incorporating 80 on a gold disk electrode $(\varnothing 1.6 \mathrm{~mm})$. The SAM successively undergoes a photochemical ring closure upon irradiation at $350 \mathrm{~nm}$ (black line) for $50 \mathrm{~min}$, then a re-opening at $750 \mathrm{~nm}$ (red line) for $30 \mathrm{~min}$ and finally an electrochemical ring closure obtained by a single potential sweeping at $10 \mathrm{mV}$ $\mathrm{s}^{-1}$ (green line). Scan rate is $20 \mathrm{~V} \mathrm{~s}^{-1}$

Although DTE systems are less prone to steric hindrance effect, yet in case of simple DTE architecture, in our case, the switching requires much more reorganization because of the presence of the bulky ruthenium acetylide moiety surrounding the DTE unit. ${ }^{[15,16]}$ Hence the isomerization probably requires larger free space than simple DTE systems.

Overall, the switching properties of the organometallics 60 and 80 in SAMs are in perfect agreement with their corresponding properties in solution. It is possible to reversibly switch from open to closed forms by using light and/or electron stimuli, along with the observation of multiple stable oxidation states at low potentials (e.g. < $1 \mathrm{~V}$ vs SCE) (Figure 7). Both SAMs incorporating 60 and 80 exhibit write-and-erase function, and can act as data storage interface, but SAM of $\mathbf{8 0}$ offers much more versatility since the information could be written either electrochemically or photochemically. In both cases, the information can be read out non-destructively by monitoring electrochemical signals at high scan rates. Importantly, all the functions can be operating at low voltage contrariwise to closely-related switches based on organic diarylethene systems ${ }^{[14,30]}$ This appealing behavior is the result of the original architecture of the organometallics allowing electron delocalization on the carbon-rich ligand including the thiophene rings.

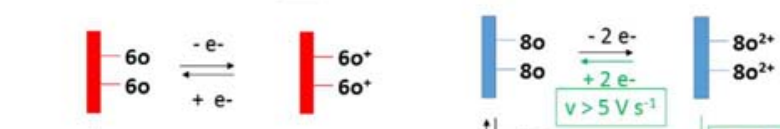

$$
\begin{aligned}
& 750 \mathrm{~nm} \Uparrow 350 \mathrm{~nm} \quad 750 \mathrm{~nm}\|350 \mathrm{~nm} \quad\| v<5 \mathrm{Vs}^{-1}
\end{aligned}
$$

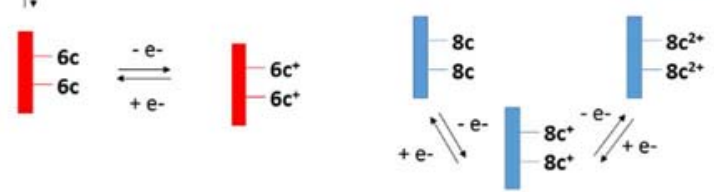

$$
\begin{aligned}
& \begin{array}{l}
\Rightarrow 4 \text { state switch } \\
\Rightarrow 0 / c \text { states: } h v \text { writing } \\
\text { e' reading }
\end{array} \\
& \Rightarrow 5 \text { state switch } \\
& \Rightarrow \text { o/c states: hv and } \mathrm{e} \text { writings }\left(v<5 V \mathrm{~s}^{-1}\right) \\
& \text { e reading }\left(v>5 V s^{-1}\right)
\end{aligned}
$$

Figure 7. Schematic diagram for electrochemical and photochemical processes for the organometallic switches 80 and 60 integrated in SAMs.

\section{Conclusions}

In summary, perfluoro-DTE units equipped with one or two acetylide-ruthenium complexes and functionalized with $\mathrm{O}-$ hexylthiol anchoring group were designed and synthesized for integration within self-assembled monolayers (SAMs) onto gold surfaces to afford switching devices. The photochemical and electrochemical properties of the two resulting organometallics were studied in solution. Both compounds display photochemically-driven switching properties, allowing reversible conversion from open to closed forms upon irradiation. In addition, the association of two ruthenium-arylacetylide complexes with the DTE unit makes possible an efficient electrochemical ring closure at low potential ( $0.5 \mathrm{~V}$ vs SCE), whereas the DTE unit associated with only one ruthenium complex cannot undergo the isomerization upon oxidation. The switching properties in solution could be successfully transferred to the complexes incorporated within SAMs. While the electrochemical switching is efficiently performed in the single-component surface confined system, interestingly, the photochemical switching is inhibited in the case of compound with one acetylide-ruthenium. Dilution with hexylthiol allows to circumvent this issue, probably because the isomerization processes induce strong reorganization within 
SAMs, hence requiring some degree of freedom to be effective. This strategy ultimately allows to obtain multifunctional materials with the possibility of combining switching triggered by electrochemical oxidation at a low potential and by light at distinct wavelengths for a write-and-erase function, along with an access to different oxidation states. Importantly, a non-destructive electrochemical read-out is achieved at a sufficiently high scan rate, which prevents any electrochemical closing. Furthermore, the two immobilized organometallics exhibit fast electron transfer kinetics. On the whole, the two surface-confined organometallic compounds exhibit appealing properties for application in molecular electronics, and particularly $\mathbf{8 0}$. Indeed, the fabrication of devices with such immobilized molecules able to be reversibly interconverted between more than two stable states is still rare and would allow for the implementation of more complex logic operations than in binary logic gates and would also increase the data storage capacity which is limited to $2^{n}$ memory units in binary system.

\section{Experimental Section}

\section{Synthetic procedures}

General Comments. The reactions were achieved under an inert atmosphere, using the Schlenk techniques. Solvents were freshly distillated under argon using standard procedures. The precursor $\left[\mathrm{Cl}(\mathrm{dppe})_{2} \mathrm{Ru}=\mathrm{C}=\mathrm{CH}-\mathrm{p}-\mathrm{C}_{6} \mathrm{H}_{5}\right](\mathrm{OTf}) \quad(1), \quad\left[\left(\left(\mathrm{CH}_{3}\right)_{2} \mathrm{CH}\right)_{3} \mathrm{Si}-\mathrm{C} \equiv \mathrm{C}-\right.$ $\left.\left(\mathrm{C}_{15} \mathrm{~S}_{2} \mathrm{~F}_{6} \mathrm{H}_{8}\right)-\mathrm{C} \equiv \mathrm{C}-\mathrm{H}\right] \quad(2),{ }^{[16]} \quad \mathrm{I}-1,4-\mathrm{C}_{6} \mathrm{H}_{4}-\mathrm{O}-\left(\mathrm{CH}_{2}\right)_{6}-\mathrm{Sac} \quad(5),{ }^{[35]}$ trans-[(dppe $\left.\left.)_{2}(\mathrm{Cl}) \mathrm{Ru}=\mathrm{C}=\mathrm{CH}-\mathrm{p}-\mathrm{C}_{6} \mathrm{H}_{4}-\mathrm{O}-\left(\mathrm{CH}_{2}\right)_{6}-\mathrm{SAc}\right)\right](\mathrm{OTf}) \quad(7),{ }^{[35]}$ were prepared as previously reported. All the reactions and handling of the compound were carried out in the dark. High resolution mass spectra (HRMS) were recorded in Rennes at the CRMPO (Centre Régional de Mesures Physiques de l'Ouest) on a ZabSpecTOF (LSIMS at $4 \mathrm{kV}$ ) spectrometer.

\section{trans- $\left[\mathrm{C}_{6} \mathrm{H}_{5}-\mathrm{C} \equiv \mathrm{C} \text {-dppe }\right)_{2} \mathrm{Ru}-\mathrm{C} \equiv \mathrm{C}-\left(\mathrm{C}_{15} \mathrm{~S}_{2} \mathrm{~F}_{6} \mathrm{H}_{8}\right)-\mathrm{C} \equiv \mathrm{C}-$}

$\left.\mathrm{Si}\left(\mathrm{CH}\left(\mathrm{CH}_{3}\right)_{2}\right)_{3}\right] \quad$ (3): In a Schlenk tube, trans$\left[(\mathrm{dppe})_{2}(\mathrm{Cl}) \mathrm{Ru}=\mathrm{C}=\mathrm{CH}-\mathrm{p}-\mathrm{C}_{6} \mathrm{H}_{5}\right](\mathrm{OTf})(1)(189 \mathrm{mg}, 0.160 \mathrm{mmol})$, $\left[\left(\left(\mathrm{CH}_{3}\right)_{2} \mathrm{CH}\right)_{3} \mathrm{Si}-\mathrm{C} \equiv \mathrm{C}-\left(\mathrm{C}_{15} \mathrm{~S}_{2} \mathrm{~F}_{6} \mathrm{H}_{8}\right)-\mathrm{C} \equiv \mathrm{C}-\mathrm{H}\right] \quad$ (2) $\quad(110 \mathrm{mg} \quad 0.192$ mmol) and $\mathrm{NaPF}_{6}(52 \mathrm{mg}, 0.32 \mathrm{mmol}$ ) were pumped under vacuum for 30 minutes. Dichloromethane $(20 \mathrm{~mL})$ and triethylamine $(0.898 \mathrm{~mL}, 6.4 \mathrm{mmol})$ were further added on the solids. The reaction mixture was stirred for 6 days and the solvent was removed under reduced pressure. The residue was taken up in THF (20 mL), filtered over an alumina plug (elution with ether), and the solvent was removed under reduced pressure. The residue was dissolved in $\mathrm{CH}_{2} \mathrm{Cl}_{2}(5 \mathrm{~mL})$ and the solution was cooled to $-50{ }^{\circ} \mathrm{C}$. Then, pentane $(30 \mathrm{~mL})$ was slowly added leading to the formation of a yellow precipitate that was further washed with pentane $(2 \times 10 \mathrm{~mL})$. Complex 3 was obtained as yellow solid (182 mg, $72 \%) .{ }^{31} \mathrm{P}$ NMR $\left(81 \mathrm{MHz}, \mathrm{CDCl}_{3}, 297 \mathrm{~K}\right)$ : $\delta$ $=55.0\left(\mathrm{~s}, \mathrm{PPh}_{2}\right) .{ }^{1} \mathrm{H} \mathrm{NMR}\left(300 \mathrm{MHz}, \mathrm{CDCl}_{3}, 297 \mathrm{~K}\right): \delta=7.76-6.87$ $\left(\mathrm{m}, 46 \mathrm{H}, \mathrm{C}_{6} \mathrm{H}_{5}+6.87 \mathrm{H}_{\mathrm{DTE}}\right), 6.11\left(\mathrm{~s}, 1 \mathrm{H}, \mathrm{H}_{\mathrm{DTE}}\right), 2.62(\mathrm{~m}, 8 \mathrm{H}$, $\mathrm{PCH}_{2} \mathrm{CH}_{2} \mathrm{P}$ ), 1.88 (s, 3H; $\mathrm{CH}_{3 \text { DTE }}$ ); 1.85 (s, 3H, $\left.\mathrm{CH}_{3 \mathrm{DTE}}\right) 1.15$ (s, $21 \mathrm{H},\left(\left(\mathrm{CH}_{3}\right)_{2} \mathrm{CH}\right)_{3} \mathrm{Si}^{13} \mathrm{C}-\mathrm{NMR}\left(400.16 \mathrm{MHz}, \mathrm{CD}_{2} \mathrm{Cl}_{2}, 297 \mathrm{~K}\right): \delta=$
143.4 ( $\underline{\mathrm{C}} \mathrm{H} 3$ thiophene), $142.3(\mathrm{~m}), 137.2$ and 136.6 (ipso- $\mathrm{C}_{6} \mathrm{H}_{5}$ ), 135.8, 134.5 and $133.8\left(o-\mathrm{C}_{6} \mathrm{H}_{5} \mathrm{dppe}\right), 131.9$ ( $\mathrm{CH}$ thiophene), 130.4 (ipso- $\mathrm{C}_{6} \mathrm{H}_{5}$ phenylacetylene), 130.1, $129.8 \quad\left(o-\mathrm{C}_{6} \mathrm{H}_{5}\right.$ phenylacetylene), 128.9 and $128.5\left(p-\mathrm{C}_{6} \mathrm{H}_{5}\right.$ dppe $), 127.6\left(m-\mathrm{C}_{6} \mathrm{H}_{5}\right.$ phenylacetylene), $127.1\left(m-\mathrm{C}_{6} \mathrm{H}_{5}\right.$ dppe), 125.2 and 123.6 and 123.4 ( $\mathrm{Cq}$ thiophene), $123.1\left(p-\mathrm{C}_{6} \mathrm{H}_{5}\right.$ phenylacetylene), 121.7, $117.6 \quad\left(-\mathrm{C} \equiv \underline{\mathrm{C}}-\mathrm{C}_{6} \mathrm{H}_{5}\right), \quad 106.6 \quad(\mathrm{Ru}-\mathrm{C} \equiv \underline{\mathrm{C}}-\mathrm{DTE}), \quad 98.2$ (DTE-C $\equiv \underline{C}-T I P S), 96.5$ (DTE- $\underline{C} \equiv C-T I P S), 31.4\left(\mathrm{~m},\left.\right|^{1} \mathrm{~J}_{\mathrm{PC}}+{ }^{3} \mathrm{JPCl}\right.$ $\left.=23 \mathrm{~Hz}, \mathrm{PCH}_{2} \mathrm{CH}_{2} \mathrm{P}\right), 18.4\left(\mathrm{CH} \underline{\mathrm{C}} \mathrm{H}_{3}\right), 14.3\left(\mathrm{CH}_{3}\right.$ DTE $), 11.3(\mathrm{CHSi})$. IR $\left(\mathrm{KBr}, \mathrm{cm}^{-1}\right): \mathrm{v}=2144(\mathrm{Si}-\mathrm{C} \equiv C), 2052(\mathrm{Ru}-\mathrm{C} \equiv C)$. HR-MS FAB $(\mathrm{m} / \mathrm{z}): 1570.3577\left(\left[\mathrm{M}^{+}\right]\right.$, calcd: 1570.3525).

trans-[ $\mathrm{C}_{6} \mathrm{H}_{5}-\mathrm{C} \equiv \mathrm{C}$-(dppe) $\left.{ }_{2} \mathrm{Ru}-\mathrm{C} \equiv \mathrm{C}-\left(\mathrm{C}_{15} \mathrm{~S}_{2} \mathrm{~F}_{6} \mathrm{H}_{8}\right)-\mathrm{C} \equiv \mathrm{C}-\mathrm{H}\right]$ (4): In a Schlenck tube, complex 3 (184 $\mathrm{mg} 0.117 \mathrm{mmol}$ ) was pumped under vacuum for 30 minutes. Then, $\mathrm{CH}_{2} \mathrm{Cl}_{2}(10 \mathrm{~mL})$ and ${ }^{\mathrm{n}} \mathrm{Bu}_{4} \mathrm{NF}$ (1M solution in THF, $0.33 \mathrm{~mL}, 0.326 \mathrm{mmol}$ ) were added on the solids. The reaction mixture was stirred for 90 minutes. The solution was washed with water $(2 \times 10 \mathrm{~mL})$ and the solvent was removed under reduced pressure. The residue was taken up with THF $(20 \mathrm{~mL})$, filtered and the solvent was removed under reduced pressure. The residue was further taken up with dichloromethane $(5 \mathrm{~mL})$ and the solution was cooled to $-50^{\circ} \mathrm{C}$. Then pentane $(30$ $\mathrm{mL}$ ) was slowly added, leading to the formation of a yellow precipitate, that was further washed with pentane $(2 \times 15 \mathrm{~mL})$. Complex 4 was obtained as a yellow solid (109 mg, 65\%). ${ }^{31} \mathrm{P}$ NMR $\left(81 \mathrm{MHz}, \mathrm{CDCl}_{3}, 297 \mathrm{~K}\right): \delta=53.1\left(\mathrm{~s}, \mathrm{PPh}_{2}\right) .{ }^{1} \mathrm{H} \mathrm{NMR}(300$ $\left.\mathrm{MHz}, \mathrm{CDCl}_{3}, 297 \mathrm{~K}\right): \delta=7.77-6.96\left(\mathrm{~m}, 45 \mathrm{H}, \mathrm{C}_{6} \mathrm{H}_{5}\right), 7.24(\mathrm{~s}, 1 \mathrm{H}$, $\left.\mathrm{H}_{\text {DTE }}\right), 6,18\left(\mathrm{~s}, 1 \mathrm{H}, \mathrm{H}_{\text {DTE }}\right) 3.44(\mathrm{~s}, 1 \mathrm{H}, \mathrm{C} \equiv \mathrm{C}-\mathrm{H}), 2.63(\mathrm{~m}, 8 \mathrm{H}$,

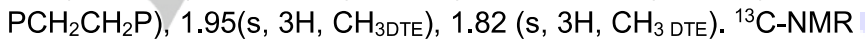
(400.16 MHz, $\left.\mathrm{CD}_{2} \mathrm{Cl}_{2}, 297 \mathrm{~K}\right): \delta=143.9$ ( $\mathrm{CCH} 3$ thiophene), 142.9 (m), 137.1 and 136.8 (ipso- $\left.\mathrm{C}_{6} \mathrm{H}_{5}\right), 135.8,134.5$ and $133.8\left(\mathrm{o}-\mathrm{C}_{6} \mathrm{H}_{5}\right.$ dppe), 133.0 ( $\mathrm{CH}$ thiophene), 130.4 (ipso- $\mathrm{C}_{6} \mathrm{H}_{5}$ phenylacetylene), 130.2, $129.8\left(o-\mathrm{C}_{6} \mathrm{H}_{5}\right.$ phenylacetylene), 128.9 and $128.5\left(p-\mathrm{C}_{6} \mathrm{H}_{5}\right.$ dppe), $127.5\left(m-\mathrm{C}_{6} \mathrm{H}_{5}\right.$ phenylacetylene), 127.1 ( $m-\mathrm{C}_{6} \mathrm{H}_{5}$ dppe), 125.3 and 123.5 and 123.3 ( $\mathrm{Cq}$ thiophene), $123.1\left(p-\mathrm{C}_{6} \mathrm{H}_{5}\right.$ phenylacetylene $), \quad 120.0, \quad 117.7 \quad\left(-\mathrm{C} \equiv \underline{\mathrm{C}}-\mathrm{C}_{6} \mathrm{H}_{5}\right), \quad 106.6$ (Ru-C $\equiv \underline{C}-D T E), 81.8$ (DTE-C $\equiv \underline{C}-H), 75.8$ (DTE- $\underline{C} \equiv \mathrm{C}-\mathrm{H})$, $31.4\left(\mathrm{~m},\left.\right|^{1} \mathrm{JPC}_{\mathrm{PC}}+{ }^{3} \mathrm{~J} \mathrm{PCl}=23 \mathrm{~Hz}, \mathrm{PCH}_{2} \mathrm{CH}_{2} \mathrm{P}\right), 14.3$ and $14.2\left(\mathrm{CH}_{3}\right.$

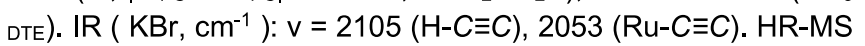
$\mathrm{FAB}+(\mathrm{m} / \mathrm{z}): 1414.2210([\mathrm{M}+]$, calcd: 1414.2191). Elemental analysis (\%) for $\mathrm{C}_{79} \mathrm{H}_{62} \mathrm{~F}_{6} \mathrm{P}_{4} \mathrm{~S}_{2} \mathrm{Ru}$ : C $67.08, \mathrm{H} 4.49$, S 4.56 (calcd: C 67.08, H 4.42, S 4.53)

trans- $\left[\mathrm{C}_{6} \mathrm{H}_{5}-\mathrm{C} \equiv \mathrm{C}\right.$-(dppe) ${ }_{2} \mathrm{Ru}-\mathrm{C} \equiv \mathrm{C}-\left(\mathrm{C}_{15} \mathrm{~S}_{2} \mathrm{~F}_{6} \mathrm{H}_{8}\right)-\mathrm{C} \equiv \mathrm{C}-\mathrm{C}_{6} \mathrm{H}_{4}-\mathrm{O}-$ $\left(\mathrm{CH}_{2}\right)_{6}$-p-SAC] (6o): In a Schlenk tube, complex 4 (108 mg, 0.076 $\mathrm{mmol}$ ) and 5 (28.9 mg, $0.076 \mathrm{mmol}), \mathrm{Pd}(\mathrm{dba})_{3}$ (14 mg, 0.015 $\mathrm{mmol}), \mathrm{PPh}_{3}(16 \mathrm{mg}, 0.061 \mathrm{mmol})$, Cul (5.8 mg, $0.030 \mathrm{mmol}$ ) were pumped under vacuum for 30 minutes. Dry THF $(2 \mathrm{~mL})$, toluene $(2 \mathrm{~mL})$ and triethylamine $(2 \mathrm{~mL})$ were added, the mixture was treated to three freeze-pump-thaw cycles and then heated to 50 ${ }^{\circ} \mathrm{C}$ under Argon for 90 minutes. The cold mixture was passed through a short column of $\mathrm{Al}_{2} \mathrm{O}_{3}$ (pentane) with increasing portion of dichloromethane, the solvent removed and the product was purified by recrystallization from DCM/pentane to give a light green solid (40 mg, 31\%). ${ }^{31} \mathrm{P}-\mathrm{NMR}$ (161.99 MHz, $\mathrm{CD}_{2} \mathrm{Cl}_{2}, 297 \mathrm{~K}$ ): $\delta=53.04\left(\mathrm{~s}, \mathrm{PPh}_{2}\right) \cdot{ }^{1} \mathrm{H}-\mathrm{NMR}\left(400.16 \mathrm{MHz}, \mathrm{CD}_{2} \mathrm{Cl}_{2}, 297 \mathrm{~K}\right): \delta=$ 7.72-6.86 (m, 50H, $\left.\mathrm{C}_{6} \mathrm{H}_{5}+\mathrm{C}_{6} \mathrm{H}_{4}-p-\mathrm{SAC}+\mathrm{H}_{\text {DTE }}\right), 6.17\left(\mathrm{~s}, 1 \mathrm{H}, \mathrm{H}_{\text {DTE }}\right)$, 
$3.97\left(\mathrm{t},{ }^{3} \mathrm{~J}_{\mathrm{H}-\mathrm{H}}=6.47 \mathrm{~Hz}, 2 \mathrm{H}, \mathrm{O}-\mathrm{CH}_{2}\right), 2.87\left(\mathrm{t},{ }^{3} \mathrm{~J}_{\mathrm{H}-\mathrm{H}}=7.31 \mathrm{~Hz}, 2 \mathrm{H}\right.$, $\left.\mathrm{S}-\mathrm{CH}_{2}\right), 2.62\left(\mathrm{~m}, 8 \mathrm{H}, \mathrm{PCH}_{2} \mathrm{CH}_{2} \mathrm{P}\right), 2.30\left(\mathrm{~s}, 3 \mathrm{H}, \mathrm{COCH}_{3}\right), 1.95$ (s, $\left.3 \mathrm{H}, \mathrm{CH}_{3 \text { DTE }}\right), 1.84$ (s, 3H, $\mathrm{CH}_{3 \text { DTE }}, 1.82-1.43\left(\mathrm{~m}, 8 \mathrm{H}, \mathrm{CH}_{2}\right) .{ }^{13} \mathrm{C}-$ NMR (400.16 MHz, $\left.\mathrm{CD}_{2} \mathrm{Cl}_{2}, 297 \mathrm{~K}\right)$ : $\delta=195.99$ (C=O), 160.1 (Cq, $\left.\mathrm{C}_{6} \mathrm{H}_{4}-\mathrm{O}\right), 143.6$ ( $\underline{\mathrm{CCH}} 3$ thiophene), 143.3, $142.7(\mathrm{~m}), 137.6$ and 137.1 (ipso- $\left.\mathrm{C}_{6} \mathrm{H}_{5}\right), 136.3,135.6,135.3,134.9$ and $134.2\left({ }^{\circ}-\mathrm{C}_{6} \mathrm{H}_{5}\right.$ dppe), $134.2\left(\mathrm{CH}, \mathrm{C}_{6} \mathrm{H}_{4}-\mathrm{O}\right), 132.3,132.4,131.6(\mathrm{CH}$ thiophene), 130.8, 130.7 (ipso- $\mathrm{C}_{6} \mathrm{H}_{5}$ phenylacetylene), 130.6, $130.2\left({ }^{\circ}-\mathrm{C}_{6} \mathrm{H}_{5}\right.$ phenylacetylene), 129.3 and $129.0\left(p-\mathrm{C}_{6} \mathrm{H}_{5}\right.$ dppe), 128.8, 128.1, 128.0 ( $m-\mathrm{C}_{6} \mathrm{H}_{5}$ phenylacetylene), $127.5\left(m-\mathrm{C}_{6} \mathrm{H}_{5}\right.$ dppe), 125.9, $125.8,124.0$ and $123.8(\mathrm{Cq}$ thiophene $), 123.5\left(p-\mathrm{C}_{6} \mathrm{H}_{5}\right.$ phenylacetylene), 121.7, $118.1\left(-\mathrm{C} \equiv \underline{\mathrm{C}}-\mathrm{C}_{6} \mathrm{H}_{5}\right), 115.1\left(\mathrm{CH}, \mathrm{C}_{6} \mathrm{H}_{4}-\mathrm{O}\right)$, $114.6\left(\mathrm{Cq}, \mathrm{C}_{6} \mathrm{H}_{4}-\mathrm{O}\right), 107.0(\mathrm{Ru}-\mathrm{C} \equiv \underline{\mathrm{C}}-\mathrm{DTE}), 94.2$ and 80.1 (DTE-C $\equiv \underline{\mathrm{C}}-\mathrm{C}_{6} \mathrm{H}_{4}-\mathrm{O}$ and DTE$\left.-\underline{\mathrm{C}} \equiv \mathrm{C}-\mathrm{C}_{6} \mathrm{H}_{4}-\mathrm{O}\right), 68.43(\mathrm{O}-\mathrm{CH} 2)$, $31.9\left(\mathrm{~m},\left.\right|^{1} \mathrm{~J}_{\mathrm{PC}}+{ }^{3} \mathrm{~J}_{\mathrm{PCl}}=23 \mathrm{~Hz}, \mathrm{PCH}_{2} \mathrm{CH}_{2} \mathrm{P}\right), 30.9(\mathrm{CH}-\mathrm{C}=\mathrm{O}), 29.9$ $(\mathrm{CH} 2), 29.4(\mathrm{CH} 2), 29.4(\mathrm{CH} 2), 28.9(\mathrm{CH} 2), 25.9(\mathrm{CH} 2), 14.8$ and $14.7\left(\mathrm{CH}_{3}\right.$ DTE$)$. IR $\left(\mathrm{KBr}, \mathrm{cm}^{-1}\right): \mathrm{v}=1689(\mathrm{C}=\mathrm{O}), 2182\left(\mathrm{C} \equiv \mathrm{C}_{-} \mathrm{C}_{6} \mathrm{H}_{4}-\right.$ O), 2052 ( $C \equiv C-R u)$. HR-MS ESI $(m / z): 1664.3218$ ([M] ${ }^{+}$, calcd 1664.3213). Elemental analysis for $2 \mathrm{C}_{93} \mathrm{H}_{80} \mathrm{O}_{2} \mathrm{~F}_{6} \mathrm{P}_{4} \mathrm{RuS}_{3} \cdot \mathrm{CH}_{2} \mathrm{Cl}_{2}$ : C 65.34, H 4.77 (Calcd: C 65.71, H 4.74).

\section{trans- $\left[\mathrm{C}_{6} \mathrm{H}_{5}-\mathrm{C} \equiv \mathrm{C}-(\text { dppe })_{2} \mathrm{Ru}-\mathrm{C} \equiv \mathrm{C}-\left(\mathrm{C}_{15} \mathrm{~S}_{2} \mathrm{~F}_{6} \mathrm{H}_{8}\right)-\mathrm{C} \equiv \mathrm{C}-\right.$}

$\mathrm{Ru}(\text { dppe })_{2}-\mathrm{C} \equiv \mathrm{C}-\mathrm{p}-\mathrm{C}_{6} \mathrm{H}_{4}-\mathrm{O}-\left(\mathrm{CH}_{2}\right)_{6}-\mathrm{SAc}$ (80): In a Schlenk tube, complex 4 (143 mg, $0.102 \mathrm{mmol})$, trans-[(dppe $)_{2}(\mathrm{Cl}) \mathrm{Ru}=\mathrm{C}=\mathrm{CH}-\mathrm{p}-$ $\left.\left.\mathrm{C}_{6} \mathrm{H}_{4}-\mathrm{O}-\left(\mathrm{CH}_{2}\right)_{6}-\mathrm{SAc}\right)\right](\mathrm{OTf})(7)$ (157 mg, $\left.0.122 \mathrm{mmol}\right), \mathrm{NaPF}_{6}(86$ $\mathrm{mg}, 0.510 \mathrm{mmol}$ ) were dried under vacuum for $30 \mathrm{~min}$. Then dichloromethane $(20 \mathrm{~mL})$, triethylamine $(2.0 \mathrm{~mL})$ were added on the solids. The reaction mixture was stirred for 4 days, then the solvents were removed under reduced pressure. The residue was taken up in THF $(20 \mathrm{~mL})$, filtered and the solvents were removed. The residue was taken up in $\mathrm{CH}_{2} \mathrm{Cl}_{2}(5.0 \mathrm{~mL})$, the solution was cooled to $-50^{\circ} \mathrm{C}$ and pentane $(30 \mathrm{~mL})$ was slowly added, leading to the formation of a light precipitate that was further washed with pentane $(3 \times 15 \mathrm{~mL})$. 80 was obtained as a light green solid (150 $\mathrm{mg}, 57 \%) .{ }^{31} \mathrm{P} \mathrm{NMR}\left(81 \mathrm{MHz}, \mathrm{CDCl}_{3}, 297 \mathrm{~K}\right): \delta=53.7\left(\mathrm{~s}, \mathrm{PPh}_{2}\right)$. ${ }^{1} \mathrm{H}$ NMR $\left(300 \mathrm{MHz}, \mathrm{CDCl}_{3}, 297 \mathrm{~K}\right): \delta=7.74-6.72\left(\mathrm{~m}, 91 \mathrm{H}, \mathrm{C}_{6} \mathrm{H}_{5}\right.$ $\left.+\mathrm{C}_{6} \mathrm{H}_{4}+2 \mathrm{H}_{\mathrm{DTE}}\right), 6.23\left(\mathrm{~s}, 2 \mathrm{H}, \mathrm{H}_{\mathrm{DTE}}\right), 3.94\left(\mathrm{t},{ }^{3} \mathrm{~J}_{\mathrm{HH}}=6.3 \mathrm{~Hz}, 2 \mathrm{H}\right.$, $\left.\mathrm{O}-\mathrm{CH}_{2}\right), 2.91\left(\mathrm{t},{ }^{3} \mathrm{~J}_{\mathrm{HH}}=6.3 \mathrm{~Hz}, 2 \mathrm{H}, \mathrm{S}-\mathrm{CH}_{2}\right) 2.62(\mathrm{~m}, 16 \mathrm{H}$, $\left.\mathrm{PCH}_{2} \mathrm{CH}_{2} \mathrm{P}\right), 2.34$ (s, $\left.6 \mathrm{H}, \mathrm{COCH}_{3}\right), 1.79\left(\mathrm{~s}, 6 \mathrm{H}, \mathrm{CH}_{3}\right.$ DTE), 1.81$1.51(\mathrm{~m}, 8 \mathrm{H}, \mathrm{CH} 2) .{ }^{13} \mathrm{C}-\mathrm{NMR}\left(400.16 \mathrm{MHz}, \mathrm{CD}_{2} \mathrm{Cl}_{2}, 297 \mathrm{~K}\right): \delta=$ $195.9(\mathrm{C}=\mathrm{O}), 155.7\left(\mathrm{Cq}, \mathrm{C}_{6} \mathrm{H}_{4}-\mathrm{O}\right), 137.2$ and $136.8\left(\right.$ ipso- $\left.\mathrm{C}_{6} \mathrm{H}_{5}\right)$, $135.9,135.8,134.5$ and $133.8\left(o-\mathrm{C}_{6} \mathrm{H}_{5} \mathrm{dppe}\right), 133.9,130.6$ (ipso$\mathrm{C}_{6} \mathrm{H}_{5}$ phenylacetylene), 130.7, $129.8\left(0-\mathrm{C}_{6} \mathrm{H}_{5}\right.$ phenylacetylene), 128.8 and $128.5 \quad\left(p-\mathrm{C}_{6} \mathrm{H}_{5}\right.$ dppe $), 128.1,127.6 \quad\left(m-\mathrm{C}_{6} \mathrm{H}_{5}\right.$ phenylacetylene), 127.1 ( $m-\mathrm{C}_{6} \mathrm{H}_{5}$ dppe), 125.22, 124.13, 124.0, 123.9, $123.3\left(\mathrm{Cq}, \mathrm{C}_{6} \mathrm{H}_{4}-\mathrm{O}\right), 123.1\left(p-\mathrm{C}_{6} \mathrm{H}_{5}\right.$ phenylacetylene $)$, 117.6 and $116.7(\mathrm{Ru}-\mathrm{C} \equiv \underline{\mathrm{C}}-), 113.8\left(\mathrm{CH}, \mathrm{C}_{6} \mathrm{H}_{4}-\mathrm{O}\right), 106.8$ and 106.6 (Ru-C $\equiv \underline{C}-D T E), 67.8(\mathrm{O}-\mathrm{CH} 2), 31.4\left(\mathrm{~m},\left.\right|^{1} \mathrm{JPC}+{ }^{3} \mathrm{JPl}_{\mathrm{PC}}=23 \mathrm{~Hz}\right.$, $\left.\mathrm{PCH}_{2} \mathrm{CH}_{2} \mathrm{P}\right), 30.4\left(\mathrm{CH}_{3}-\mathrm{C}=\mathrm{O}\right), 29.6\left(\mathrm{CH}_{2}\right), 29.3\left(\mathrm{CH}_{2}\right), 29.0\left(\mathrm{CH}_{2}\right)$, $28.5\left(\mathrm{CH}_{2}\right), 25.6\left(\mathrm{CH}_{2}\right), 14.4\left(\mathrm{CH}_{3 \mathrm{DTE}}\right)$. IR $(\mathrm{KBr}): \mathrm{v}=1687 \mathrm{~cm}^{-1}$ $(\mathrm{C}=\mathrm{O}), \quad 2054 \mathrm{~cm}^{-1} \quad(\mathrm{C} \equiv \mathrm{C})$. Elemental analysis (\%) for $\mathrm{C}_{147} \mathrm{H}_{128} \mathrm{~F}_{6} \mathrm{O}_{2} \mathrm{P}_{8} \mathrm{Ru}_{2} \mathrm{~S}_{3} . \mathrm{CH}_{2} \mathrm{Cl}_{2}: \mathrm{C}$ 66.31, H 4.90 (calcd: C 66.54, $\mathrm{H}$ 4.90).

\section{Isomerization studies}

UV-vis irradiations were performed with a LS series Light Source of $A B E T$ technologies, Inc (150 W xenon lamp), with single wavelength light filters of "350FS 10-25", "450FS 20-25", "650FS 10-25" and "750FS 40-25". UV-vis-NIR spectra were recorded with a Cary 5000 apparatus. Irradiation of SAMs was performed with samples being immerged in a $\mathrm{CH}_{2} \mathrm{Cl}_{2}$ solution to help the DTE rearrangement.

\section{Electrochemistry}

Cyclic Voltammetry experiments were performed in dry (freshly distilled) and throughly degassed $\mathrm{CH}_{2} \mathrm{Cl}_{2}$ containing $0.2 \mathrm{M}$ $\mathrm{Bu}_{4} \mathrm{NPF}_{6}$ under an $\mathrm{Ar}$ blanket. A Pt wire or a Pt grid serves as as counter electrode and a SCE reference electrode fitted with a bridge containing $0.2 \mathrm{M} \mathrm{Bu}_{4} \mathrm{NPF}_{6}$ in $\mathrm{CH}_{2} \mathrm{Cl}_{2}$. Measurements in solution were carried out using an Eco Chemie Autolab PGSTAT 30 potentiostat with a Pt disk as the working electrode, and decamethylferrocene was added as internal reference. The voltammograms of SAMs on gold electrodes of $1.6 \mathrm{~mm}$ diameter were recorded using an Eco Chemie BV Autolab PGSTAT302N potentiostat equipped with FRA2.V10 and SCAN250 modules for high speed and iR compensation measurements. The voltammograms of SAMs on gold ultramicroelectrodes were recorded using a homemade potentiostat with fine control over gain and iR compensation, coupled with an Agilent Technologies $80 \mathrm{mHz}$ Function/Arbitrary Waveform Generator 33250A, an Agilent Technologies $500 \mathrm{MHz}$ infiniium Oscilloscope and a Aoip MNK 179 Multimeter. Surface concentration $(\Gamma)$ was determined from Faraday's law, $\Gamma=Q / n F A$ where $Q$ is the charge obtained from the inetgration of the area under the voltammetric peaks, $n$ is the number of electrons involved in the electron-transfer process, $F$ is the Faraday constant and $A$ is the geometric area of the electrodes.

Estimation of the electronic rate constant for the immobilized $\mathbf{8 0}$ was achieved considering a simple Butler-Volmer law for the electron transfer and transfer coefficient equal to 0.5 applied to an immobilized species. Numerical simulations were performed with the KISSA-1D software package (KISSA software for simulation of electrochemical reaction mechanisms of any complexity) and using the default parameters for adsorbed species. ${ }^{[43,44]}$

\section{SAMs preparation}

Solutions of the complexes $(1 \mathrm{mg} / \mathrm{mL})$ in $\mathrm{CH}_{2} \mathrm{Cl}_{2}$ were prepared under inert atmosphere in a glovebox. Both open and closed forms of the complexes were used, and obtained upon irradiation at $750 \mathrm{~nm}$ or $350 \mathrm{~nm}$, respectively, for $1 \mathrm{~h}$. To the thioacetateprotected complexes solutions, $\mathrm{NH}_{4} \mathrm{OH}\left(28 \%\right.$ in $\left.\mathrm{H}_{2} \mathrm{O}\right)$ was added $(1 \mu \mathrm{L} / \mathrm{mL})$ and the solutions were stirred over 30 minutes to yield the deprotected thiols. The mixed SAMs preparation solutions were obtained by addition of 5 or 10 eq. of hexanethiol to the solutions prepared as described above. The SAMs were prepared on $\mathrm{Au}$ disk electrodes from $\mathrm{CH}$ instruments, Inc. (diameter 1.6 $\mathrm{mm}$ ) or homemade Au ultramicroelectrodes (diameter 5,10 or 25 $\mu \mathrm{m}$ ) or Au plates of approximately $1 \mathrm{~cm}^{2}$ area (Au deposited onto silicon wafer with a layer thickness of $1000 \AA$ ) purchased from Sigma Aldrich. Prior to functionalization, the Au electrode surface 
was thoroughly polished using alumina suspension $(0.3 \mu \mathrm{m})$, then extensively rinsed with ultrapure $\mathrm{H}_{2} \mathrm{O}(18.2 \mathrm{M} \Omega \cdot \mathrm{cm})$. Following the polishing treatment, they were cleaned by immersion in Piranha solution, rinsed with ultrapure $\mathrm{H}_{2} \mathrm{O}$ and high purity EtOH and dried under a stream of argon. The Au plates were cleaned by immersion in a Piranha solution, rinsing with semiconductor grade MOS $\mathrm{H}_{2} \mathrm{SO}_{4}(96 \%)$, then rinsed thoroughly with ultrapure $\mathrm{H}_{2} \mathrm{O}$ and high purity $\mathrm{EtOH}$, and finally dried under a stream of argon. Caution! Piranha solution is a very strong oxidant and is extremely dangerous to work with; it should be handled very carefully. The surface functionalization was achieved by soaking the supports in each preparation solution for 16 to 48 hours in a glovebox. After formation of the SAM, the gold supports were gently rinsed with freshly distilled $\mathrm{CH}_{2} \mathrm{Cl}_{2}$.

\section{SAMs characterization}

SAMs were characterized by cyclic voltammetry, contact angle measurements, and XPS spectroscopies.

Contact angle measurements were performed on a Easy Drop goniometer (Krüss) equipped with a camera using sessile drop method ( $2 \mu \mathrm{L}$ of ultrapure water drops). Contact angles were calculated over an average of 5 measurements. They were determined using a tangent or circle fitting model.

X-ray photoelectron spectroscopy data have been collected using a Kratos Axis Nova spectrometer using the Al K $\alpha$ X-ray source working at $1486.6 \mathrm{eV}$ and using a spot size of $0.7 \times 0.3 \mathrm{~mm}^{2}$.
Survey spectra $(0-1000 \mathrm{eV})$ were acquired with an analyzer pass energy of $160 \mathrm{eV}(0.5 \mathrm{eV} / \mathrm{step})$; high resolution spectra used a pass energy of $40 \mathrm{eV}(0.1 \mathrm{eV} / \mathrm{step})$. Binding energies were referenced to $\mathrm{C} 1 \mathrm{~s}$ peak at $285 \mathrm{eV}$. The core level spectra were peak-fitted using the CasaXPS software, Ltd., version 2.3.18).

\section{Acknowledgements}

This work was supported by the Universite de Rennes 1, the CNRS, the Agence Nationale de la Recherche (RuOxLux - ANR12-BS07-0010-01)). AM thank the Région Bretagne (SAD Modulum), and $\mathrm{YMH}$ and $\mathrm{XH}$ the university of Rennes 1 for their grants. J. Hamon (Institut des Matériaux de Nantes, Nantes, France) is acknowledged for his help in the X-ray photoelectrons spectroscopy experiments. Prof. I. Svir, C. Amatore and O. Klymenko are warmly thanked for providing KISSA Software.

Keywords: molecular switch SAMs • electron transfer • photoswitching 
Entry for the Table of Contents (Please choose one layout)

Layout 1:

\section{FULL PAPER}

$\begin{aligned} & \text { SAMs of } \\ & \text { organometallics }\end{aligned}$
multifunctional
combining afford
photoswitching at remarkably low
voltage and fast nondestructive
electrochemical read-out.

${ }^{1}$ B. L. Feringa, W. R.Browne, Molecular Switches. Eds. Wiley-VCH, Weinheim, Germany, 2011.

2 R. Goestl, A. Senf, S. Hecht, Chem. Soc. Rev. 2014, 43, 1982-1996.

${ }^{3}$ M. Irie, T. Fulcaminato, K. Matsuda, S. Kobatake, Chem. Rev. 2014, 114, 12174-12277

${ }^{4}$ S. Erbas-Cakmak, D. A. Leigh, C. T. McTernan, A. L. Nussbaumer, Chem. Rev. 2015, 115, 10081-10206

${ }^{5}$ R. Klajn, Chem. Soc. Rev. 2014, 43, 148-184

${ }^{6}$ G. Guirado, C. Coudret, M. Hliwa, J.-P. Launay, J. Phys. Chem. B, 2005, 109, 17445-17459

7 W.R. Browne, J.J.P. de Jong, T. Kudernac, M. Walko, L.N. Lucas, K. Uchida, J.H. van Esch, B.L. Feringa, Chem. Eur. J. 2005, 11, 6430-6441

${ }^{8}$ B. Gorodetsky, H. D. Samachetty, R. L. Donkers, M. S. Workentin, N. R. Branda, Angew. Chem. Int. Ed. 2004, 43, 2813-2815

${ }^{9}$ B. Gorodetsky, N. R. Branda, Adv. Funct. Mater. 2007, 17, 786-796

${ }^{10}$ R. Baron, A. Onopriyenko, O. Lioubasheviski, I. Willner, S. Wang, H. Tian, Chem. Commun. 2006, 2147-2149.

${ }^{11}$ W. R. Browne, T. Kudernac, N. Katsonis, J. Areephong, J. Hjelm, B. L. Feringa, J. Phys. Chem. C 2008, 112, 1183-1190

12 Y. Nakashima, Y. Kajiki, S. Fukumoto, M. Tagushi, S. Nagao, S. Hirota, T. Kawai, J. Am. Chem. Soc. 2012, 134, 19877-19883

13 J.P. Calupitan, T. Nakashima, Y. Hashimoto, T. Kawai, Chem., Eur. J. 2016, 22, 10002-10008

${ }^{14}$ E.C. Harvey, B.L. Feringa, J.G. Vos, W.R Browne, M.T. Pryce, Coord. Chem. Rev. 2015, 282-283, 77-86.

15 Y.F. Liu, C. Lagrost, K. Costuas, N. Tchouar, H. Le Bozec, H., S. Rigaut, S. Chem. Commun. 2008, 46, 6117-6119

16 Y.F. Liu, C.M. Ndiaye, C. Lagrost, K. Costuas, S. Choua, P. Turek, L. Norel, S. Rigaut, Inorg. Chem. 2014, 53, 8172-8188.

17 Y.M. Hervault, C. M. Ndiaye, L. Norel, C. Lagrost, S. Rigaut, Org; Lett. 2012, 14 , 4454-4457

18 a) Y. Tanaka, T. Ishisaka, A. Inagaki, T. Koike, C. Lapinte, M. Akita Chem. Eur. J. 2010, 16, 4762; b) K. Motoyama, T. Koike, M. Akita, Chem. Commun. 2008, 5812-5814

19 F.B. Meng, Y.M. Hervault, Q. Shao, B.H. Hu, L. Norel, S. Rigaut, X.D. Chen, Nature Commun. 2014, 5:3023

${ }^{20}$ T. Kudernac, N. Katsonis, W.R. Browne, B.L. Feringa, J. Mater. Chem. 2009, 19, 7168-7177.

21 T; Kondo, K. Uosaki, J. Photochem. Photobiol. C: Photochemistry Reviews 2007, 8, 17-34

22 D. Taherinia, D.C. Frisbie, J. Phys. Chem. C 2016, 120, 6442-6449

23 T. Kudernac, S.J. van der Molen, B.J. van Wees, B.L. Feringa, Chem. Commun. 2006, 3597-3599.

${ }^{24}$ S.V. Snegir, P. Yu, F. Maurel, O.L. Kapitanchuk, A.A. Marchenko, E. Lacaze Langmuir, 2014, 30, 13556-13563.

25 T.C. Pijper, O. Ivashenko, M. Walko, P. Rudolf, W.R. Browne, B.L. Feringa, J. Phys. Chem C 2015, 119, 3648-3657.

26 T.C. Pijper, T. Kudernac, W.R. Browne, B.L. Feringa, J. Phys. Chem. C 2013, 117, 17623-17632.

27 A. Arramel, T.C. Pijper, T. Kudernac, N. Katsonis, N. van der Maas, B.L. Feringa, B.J. van Wees, Nanoscale, 2013, 5, 9277-9282.

28 J. Areephong, W.R. Browne, N. Katsonis, B.L. Feringa, Chem. Commun. 2006, 3930-3939.

29 K. Uchida, Y. Yamanoi, T. Yonezawa, H. Nishihara, J. Am. Chem. Soc. 2011, 133, 9239-9241

30 H. Logtenberg, W.R. Browne, Org. Biomol. Chem. 2013, 11, 233-243.

${ }^{31}$ K. Matsuda, M. Ikeda, M. Irie, Chem. Letter. 2004, 33, 456-457

${ }^{32}$ A. Mulas, Y.M. Hervault, X. He, E. Di Piazza, L. Norel, S. Rigaut, C. Lagrost, Langmuir 2015, 31, 7138-7145

${ }^{33}$ A. Mulas, Y.M. Hervault, L. Norel, S. Rigaut, C. Lagrost, ChemElectroChem, 2015, 2, 1799-1805

${ }^{34}$ H. Zhu, S.J. Pookpanratana, J.E. Bonevich, S.N. Natoli, C.A. Hacker, T. Ren, J.S. Suehle, C.A. Richter, Q. Li, ACS Appl. Mater. Interfaces 2015, 7, 2730627313

${ }^{35}$ A. Benameur, P. Brignou, E. Di Piazza, Y.M. Hervault, L. Norel, S. Rigaut, New J. Chem. 2011, 35, 2105-2113.

${ }^{36}$ N. Gauthier, N. Tchouar, F. Justaud, G. Argouarch, M.P. Cifuentes, L. Toupet, D. Touchard, J.F. Halet, S. Rigaut, M.G. Humphrey, K. Costuas, F. Paul, Organometallics 2009, 28, 2253-2266. 
${ }^{37}$ H. Valkenier, E.V. Huisman, P.A. van Hal, D.M. de Leueuw, R.C. Chiechi, J.C. Hummelen, J. Am. Chem. Soc. 2011, 133, 4930-4939.

38 J.M. Tour, L. Jones II, D.L. Pearson, J.J.S. Lamba, T.P. Burgin, G.M. Whitesides, D.L. Allara, A.N. Parikh, S.V. Atre, J. Am. Chem. Soc., 1995, 117, 95299534.

39 J.H Moore, R. Jr Colorado, H.J. Lee, A.C. Jamison, T.R. Lee, Langmuir, 2013, 29, 10674-10683.

40 D.G. Castner, K. Hinds, D.W. Grainger, Langmuir, 1996, 12, 5083-5086

41 T. Kudernac, N. Katsonis, W.R. Browne, B.L. Feringa, J. Mater. Chem. 2009, 19, 7168-7177.

42 E. Laviron, J. Electroanal. Chem. 1979, 101, 19-28.

43 C. Amatore, O. Klymenko, I. Svir Electrochem. Commun. 2010, 12, 1165-1169.

${ }^{44}$ KISSAGroup web site address: http://www.kissagroup.com/

45 D.T. Valley, M. Onstott, S. Malyk, A.V. Benderskii, Langmuir, 2013, 29, 11623-11631

46 U. Jung, O. Filinova, S. Kuhn, D. Zargarani, C. Bornholdt, R. Herges, O. Magnussen, Langmuir, 2010, 26, 13913-13923.

47 T. Moldt, D. Brete, D. Przyrembel, S. Das, J.R. Goldman, P.K. Kundu, C. Gahl, R. Klajn, M. Weinelt, Langmuir, 2015, 31, $1048-1057$.

48 M. Kaneta, T. Honda, K. Onda, M. Han, New J. Chem. 2017, 41, 1827-1833 